\title{
Od Kołomyi do Krakowa. Przyczynek do biografii Stanisława Daczyńskiego (1856-1941)
}

\author{
From Kolomyia to Krakow. A Contribution \\ to Biography of Stanisław Daczyński \\ (1856-1941)
}

\begin{abstract}
Abstrakt
W artykule została przybliżona sylwetka malarza Stanisława Daczyńskiego (1856-1941), ucznia Jana Matejki, który - po zakończonych studiach malarskich i wyjeździe z Krakowa - pracował w szkole garncarskiej w Kołomyi na Pokuciu. Stan badań nad działalnością Stanisława Daczyńskiego jest znikomy. Niniejszy artykuł jest dalszą częścią publikowanych już uprzednio przez autora opracowań dotyczących tego malarza i ma na celu przywrócenie kulturze polskiej tej postaci oraz przedstawienie szerszego kontekstu historycznego, w którym przyszło mu żyć i tworzyć. W pracy podano informacje, które udało się uzyskać na podstawie archiwaliów znajdujących się w Bibliotece Jagiellońskiej (korespondencja z malarzem Walerianem Krycińskim) oraz kwerend przeprowadzonych w archiwach polskich, a także informacji pozyskanych z własnych zbiorów autora. Podczas badań zastosowano metodę analizy historycznej i antropologicznej wymienionych materiałów źródłowych i na ich bazie dokonana została częściowa rekonstrukcja życia pokuckiego malarza. Skupiono się na wybranych aspektach jego
\end{abstract}


życia prywatnego i zawodowego w Kołomyi, Wiedniu, Bochni, Zakopanem i Krakowie. Ustalono też datę narodzin i śmierci oraz miejsca pochówku malarza i jego żony - Stefanii Zajączkowskiej. Artykuł uzupełniono materiałem ikonograficznym: rysunkami malarza, przedstawieniami jego postaci oraz miejsc, z którymi był związany. Mają one dopełnić sylwetkę Stanisława Daczyńskiego oraz kontekst kulturowy czasów, w których żył i na które oddziaływał.

Słowa klucze: Stanisław Daczyński, Walerian Kryciński, Stefania Daczyńska, Jan Daczyński, Kołomyja, Lwów, Wiedeń, Bochnia, Zakopane, Kraków

\begin{abstract}
The article presents the painter Stanisław Daczyński (1856-1941), a student of Jan Matejko, who having completed his art studies and leaving Krakow worked at a pottery school in Kolomyia in Pokuttia. There has been scarcely any research conducted about the life of Stanisław Daczyński. The present article is a continuation of the studies on this painter, previously published by the author, and aims to bring him back to Polish culture and outline closer the historical background in which he functioned. The paper presents the outcome of the research conducted in the Jagiellonian Library (mainly the correspondence with a fellow artist Walerian Kryciński) and in several Polish archives, as well as information obtained from the author's own collection. The study method used a historical and anthropological analysis of the source materials. The article reconstructs the social and cultural background of the Pokuttia, where the painter lived and worked. It also outlines his personal and professional life in Kolomyia, Vienna, Bochnia, Zakopane and Krakow. Moreover, it solves the dates of birth and death of the artist and his wife, Stefania Zajączkowska, and identifies the place of their burial. To illustrate the painter's activity, the article is supplemented with iconography: his drawings and the photographs of him and the places he was associated with. They are meant to complement the presented profile of Stanisław Daczyński and the cultural context of the environment in which he lived and which he influenced.
\end{abstract}

Keywords: Stanisław Daczyński, Walerian Kryciński, Stefania Daczyńska, Jan Daczyński, Kolomyia, Lviv, Vienna, Bochnia, Zakopane, Krakow 


\section{Wprowadzenie}

Uczniowie Jana Matejki ${ }^{1}$ dzielą się na tych, którzy znaleźli swoje zasłużone miejsce w kanonie historii sztuki i kultury polskiej, jak i na tych, których drogi powiodły w różne miejsca i stali się często niemal anonimowi ${ }^{2}$. Jednym $z$ nich jest - urodzony w Nowym Wiśniczu 3 lutego 1856 r. - Stanisław Daczyński. Stanisław, po ukończeniu studiów w Szkole Sztuk Pięknych w Krakowie w 1878 r. oraz krótkim epizodzie pracy malarskiej w Krakowie, osiadł na długie lata w Kołomyi ${ }^{3}$. Gdyby nie listy pisane do przyjaciół oraz odnaleziony zbiór rysunków i - cyklicznie $\mathrm{w}$ różnych okolicznościach odnajdywane dokumenty związane $\mathrm{z}$ jego życiem, być może Daczyński byłby znany tylko z kilku obrazów, które zachowały się w muzeach państwowych, w zbiorach prywatnych, oraz $\mathrm{z}$ informacji w katalogu dzieł zaginionych lub zniszczonych $\mathrm{w}$ czasie II wojny światowej".

Można zadać pytanie, czy Daczyński - jako malarz - był znaczący w swoim okresie. Zdaje się, że tak, choć nie należał do awangardy i głównego nurtu twórców. Nieliczne - odnalezione obecnie ślady jego działalności - dowodzą tego, że był artystą rozpoznawalnym i mógł odnieść znaczny sukces w tej dyscyplinie sztuki. Świadczyć mógłby o tym choćby jeden z komentarzy prasowych do jego prac prezentowanych na rocznej wystawie w Akademii Sztuk Pięknych w Warszawie. W 1883 r. publicysta-krytyk „Gazety Polskiej” pisał: „Pan Daczyński znów staje jako współzawodnik Brandta w scenach stepowych, na których dużo

1 Jan Matejko (1838-1893) - polski malarz, profesor. Vide: Maria Szypowska, Jan Matejko wszystkim znany (Poznań: Zysk i S-ka, 2016).

2 Uczniom Matejki poświęcona była wystawa w Muzeum Śląskim w 2004 r. Vide: Katarzyna Jarmuł-Niemczyk, Izabela Kania, Artyści ze szkoły Jana Matejki: Wystawa jubileuszowa w 80. rocznicę początków i w 20. rocznicę restytucji Muzeum Śląskiego w Katowicach (Katowice: Muzeum Śląskie, 2004). Na stronach 57 i 226 wymieniony jest też Stanisław Daczyński.

3 Vide: Krzysztof Duda, „Pokuckie i huculskie inspiracje twórczości Stanisława Daczyńskiego w świetle listów do Seweryna Böhma”, w Kołomyja, Pokucie i Huculszczyzna w II Rzeczpospolitej. Wybrane zagadnienia, red. Adam Adrian Ostanek Aleksander Smoliński (Warszawa: Wydawnictwo Stara Szuflada, 2017), 12.

4 Vide: np.: Dariusz Markowski, „Straty wojenne malarstwa w zbiorach Muzeum Okręgowego im. Leona Wyczółkowskiego w Bydgoszczy", Cenne, bezcenne, utracone. Valuable, Priceless, Lost 2/51 (2007): 29. Autor w artykule wspomina o obrazach Daczyńskiego, które mogły zostać spalone w Trzcińcu lub też zostały skradzione albo wywiezione do Niemiec. Były to skatalogowane obrazy olejne: Jeździec Turecki z buńczukiem z 1884 r. oraz Tatar na koniu. 
kozackich koni i dzikich postaci”' Zestawienie tych dwóch artystów w jednym rzędzie może wskazać, że działalność Stanisława Daczyńskiego warto nadal badać, a być może przyniesie to dalsze odkrycia w zakresie historii kultury polskiej. Daczyński był także doceniony przez krakowskie Towarzystwo Przyjaciół Sztuk Pięknych. W gmachu przy pl. Szczepańskim miał Daczyński swoją wystawę, a towarzystwo prowadziło także promocję jego dzieł. Doczekał się również swojej noty biograficznej $\mathrm{w}$ wydanym przez nie pamiętniku' ${ }^{6}$.

Kołomyjskie losy Stanisława Daczyńskiego jako malarza chcącego istnieć nadal w środowisku krakowskim i warszawskim udało się - w niewielkim stopniu - przybliżyć w artykule Pokuckie i huculskie inspiracje twórczości Stanisława Daczyńskiego w świetle listów do Seweryna Böma ${ }^{7}$. Zbiór listów do krakowskiego mecenasa sztuki - Seweryna Böma ${ }^{8}$ -

5 Zaremba, „Roczna wystawa w akademii sztuk pięknych”, w Gazeta Polska 170 (1.08.1883): 2 .

6 Informacje o Stanisławie Daczyńskim, wraz z jego zdjęciem, znajdujemy w zredagowanym przez Emmanuela Swieykowskiego Pamiętniku Towarzystwa Przyjaciót Sztuk Pięknych w Krakowie. Biogram Daczyńskiego brzmi następująco: „Daczyński Stanisław (Leopold Maksymilian), ur. w 1856 r. w Wiśniczu w Bocheńskiem. Do szkół średnich, realnych uczęszczał początkowo w Bochni, następnie w Krakowie, a w 1875 r. wstąpił do ówczesnej Szkoły sztuk pięknych w Krakowie, a po ukończeniu tejże został przyjęty do szkoły kompozycyjnej pod osobistym kierownictwem Matejki, gdzie pozostawał przez lat trzy, t. j. aż do 1884 r. włącznie. Studyował również pod kierunkiem prof. Łuszczkiewicza, Szynalewskiego, Cynka, Jabłońskiego, Grabińskiego i Löflera. Najważniejsze prace wystawione oraz otrzymane za nie odznaczenia: W Tow. Przyj. sztuk pięknych w Krakowie wystawił w 1884 r. «Branki» (epizod z najazdów tatarskich w XVII. w.), «Na czatach», «Tatar», «Dumki ukraińskie», «Przez stepy», «Na stanowisku», «Z polowań na Pokuciu», «Przystanek na polowaniu», «Przed miotem», «Z nad Dniestru», «Przy myśliwskiem ognisku», «Z polowania na niedźwiedzie», i wiele innych, przeważnie z dziedziny łowieckiej na tle swojskiem, ze szczególnem uwzględnieniem cech etnograficznych. Na wystawie sztuki polskiej w Krakowie w 1887 r. otrzymał medal brązowy za prace dekoracyjne. Na wyst. kraj. we Lwowie w $1894 \mathrm{r}$. medal srebrny za obraz myśliwski «Przed miotem». Od 1888 roku Daczyński Stanisław jest nauczycielem rysunku i dekoracyi przy Szkole ceramicznej w Kołomyi, gdzie otrzymał w ciągu swej działalności «list szczególnego uznania» z Wydziału kraj. za wzięcie udziału w wyst. kraj. we Lwowie w r. 1894 w pracach dekoracyjnych ceramicznych. Kolegował się z Kossowskim, Hernciszem, Krzeszem, Fałatem, Styką, Buchbinderem, Zembaczyńskim, ś. p. Sokołowskim i Źmurką. Przygotowuje wydanie pamiętnika, który ma się ukazać pośmiertnie. Wystawia u nas 1879-1896 r. Miejsce obecnego stałego pobytu: Kołomyja”, Emmanuel Swieykowski, Pamiętnik Towarzystwa Przyjaciół Sztuk Pięknych w Krakowie 1854-1904: pięćdziesiąt lat działalności dla sztuki ojczystej (Kraków: Towarzystwo Sztuk Pięknych w Krakowie, 1906), 53-54.

7 Vide: Duda, „Pokuckie i huculskie inspiracje”, 10-31.

8 Seweryn Böhm (1833-1921) - sekretarz i wiceprezes Towarzystwa Przyjaciół Sztuk Pięknych w Krakowie, mecenas artystów malarzy. Vide: Listy Stanisława Wyspiańskiego. Różne - do wielu adresatów, red. Maria Rydlowa (Kraków: Wydawnictwo Literackie, 1998), 486. 
umożliwił spojrzenie na Daczyńskiego jako na artystę inspirującego się sztuką mieszkańców Pokucia i Huculszczyzny i - co pozostało w jego szkicach - dokumentującego ich życie oraz miejsca. Dzięki tej korespondencji udało się również zobaczyć dość skromne życie malarza, który w poszukiwaniu pracy trafił na prowincję Galicji. Z listów wynikało, że tęsknił za środowiskiem, które opuścił, i starał się podtrzymywać z nim kontakt. Jednocześnie - jak wielu młodych i zdolnych ludzi tego okresu zdawał sobie sprawę, że wejście na salony sztuki wiąże się z posiadaniem sporych środków finansowych lub też hojnego mecenasa. Tych - pochodzący z urzędniczej, ale niezbyt majętnej rodziny - artysta nie posiadał, natomiast praca, którą wykonywał w Kołomyi, nie dawała mu zbytnich szans na zdobycie finansów ani też nie była rozwijająca.

Zamysłem obecnego artykułu jest przybliżenie nowych informacji dotyczących biografii Daczyńskiego, które udało się uzupełnić dzięki kwerendom. W sposób szczególny, choć w minimalnym stopniu - idąc tropem poprzedniej publikacji - zostanie zaprezentowany kontekst kulturowy jego życia codziennego w Kołomyi. Możemy tego dokonać dzięki nowym materiałom archiwalnym, jakimi są - zachowane i ujawnione po latach przez Bibliotekę Jagiellońską - jego listy do Stanisława Krycińskiego ${ }^{9}$. Losy obu malarzy wstępnie splotły się w Krakowie na studiach w Szkole Sztuk Pięknych, ale zdaje się, że najbardziej i najintensywniej rozwijały się w Szkole Garncarskiej Kołomyi ${ }^{10}$, a następnie możemy je śledzić poprzez odnalezione materiały epistolograficzne.

Druga część artykułu to próba rekonstrukcji losów jego rodziny i jego samego. Analiza historyczna opierać się będzie na kwerendach archiwalnych oraz materiałach autora, które w bardzo szczątkowym zakresie dają możliwość doprecyzowania danych biograficznych Daczyńskiego.

Celem naświetlenia kontekstu kulturowego epoki i zwyczajów, które stosowano na co dzień, w pracy przywołane zostaną niektóre oryginalne teksty źródłowe, jak też i materiał wizualny. Da to możliwość wglądu w stan mechanizmów oraz motywów działań mieszkańców Galicji

9 Walerian Kryciński (1852-1929) - polski malarz, grafik, ceramik i pedagog. W latach 1880-1898 dyrektor i nauczyciel w Szkole Garncarskiej w Kołomyi. Od 1898 r. dyrektor lwowskiej Szkoły Przemysłu. Po przejściu na emeryturę powrócił do Krakowa, gdzie zmarł. Autor książki: Nowe metody nauczania rysunków odręcznych, zdobniczych i malarstwa dekoracyjnego w szkołach różnego typu według planów Min. WRiOP (Lwów: wydawnictwo, 1926). Vide: Irena Huml, „Kryciński Walerian”, w Polski Słownik Biograficzny, t. 15, red. Emanuel Rostworowski (Wrocław-Warszawa-Kraków: Polska Akademia Umiejętności, 1970), 453-454.

10 O „Szkole Garncarskiej” w Kołomyi pisali np.: Bohdan Mardyrosiewicz, „Szkoła Garncarska w Kołomyi”, w Swiat: dwutygodnik ilustrowany 4 (1891): 225-234, Tadeusz Seweryn, Pokucka majolika ludowa (Kraków: Polska Akademia Umiejętności, 1929), 20-23. 
w drugiej połowie XIX i początku XX w. W przypisach zamieszczono także komentarze badaczy tego obszaru kulturowego, które mają za zadanie rozjaśnić i uzupełnić narrację prowadzoną w tekście.

Ryc. 1. Zdjęcie Stanisława Daczyńskiego - 1906 r.

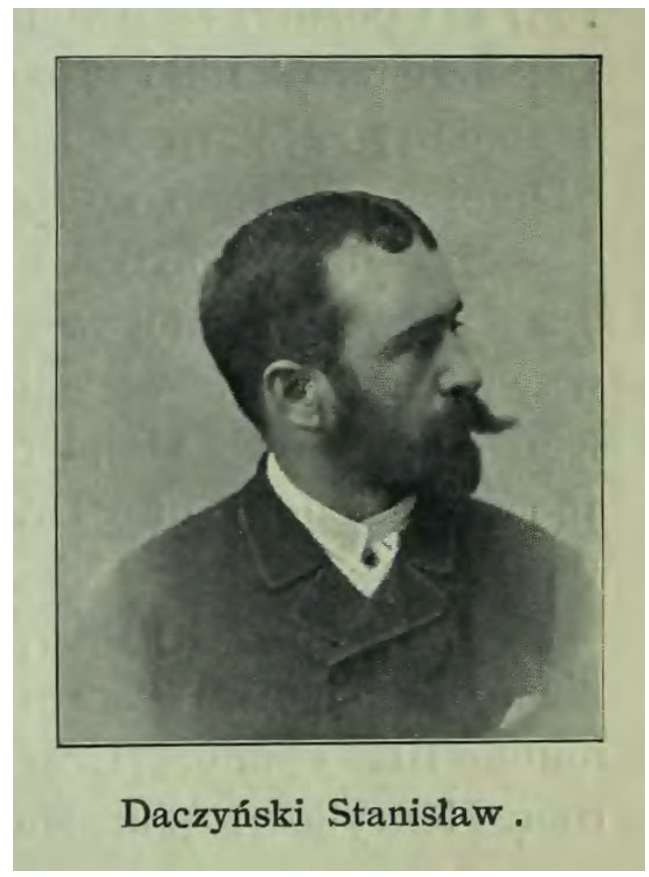

Źródło: Swieykowski, Pamiętnik Towarzystwa Przyjaciół Sztuk Pięknych w Krakowie 1854-1904: pięćdziesiąt lat działalności dla sztuki ojczystej, 53.

\section{Korespondencja Stanisława Daczyńskiego z XIX w.}

Zanim podejmiemy rekonstrukcję korespondencji, przyjrzyjmy się wczesnej aktywności Daczyńskiego w Kołomyi, by choć w niewielkim stopniu dotknąć tajemnicy jego życia w tym wielobarwnym i wielokulturowym świecie Pokucia. Stanisław Daczyński trafił do szkoły Kołomyi w 1884 lub 1985 r. Szczegółowej daty niestety na chwilę obecną nie udało się określić. Nie wiemy, czy jadąc tam, myślał, że zwiąże się z tym miastem na ponad trzydzieści lat, choć zapewne zdawał sobie zapewne sprawę z faktu, że jego pobyt będzie miał dłuższy charakter. Do Kołomyi 
trafił - jak podają źródła pisane - dzięki Walerianowi Krycińskiemu ${ }^{11}$; podobnie zresztą jak i Stanisław Dębicki ${ }^{12}$. Nie wiemy jednak, czy został polecony przez kogoś, czy też Kryciński znał się na jego warsztacie i chciał mieć w swojej szkole dobrego specjalistę. Za tą drugą hipotezą może przemawiać fakt, że - jak już wspomniano - obaj studiowali w krakowskiej Szkole Sztuk Pięknych, Kryciński w latach 1872-1875, zaś Daczyński od 1873 do 1878 r. Obaj mieli też wspólnych mistrzów w Krakowie: Władysława Łuszczkiewicza ${ }^{13}$, Feliksa Szynalewskiego ${ }^{14}$ oraz Jana Matejkę.

W każdym razie ich losy na dłuższy czas związały się właśnie w Kołomyi, tym pokuckim miasteczku, które wówczas stawało się bardzo sławne z powodu eksploracji znajdujących się w Słobodzie Rungurskiej źródeł ropy naftowej. W związku z tym wytworzył się mit Kołomyi jako miasta, w którym można spotkać ludzi z całej Europy ${ }^{15}$.

11 Mardyrosiewicz, „Szkoła Garncarska w Kołomyi”, 229.

12 Vide: Tadeusz Dobrowolski, Sztuka Młodej Polski (Warszawa: PWN, 1963), 404.

13 Władysław Łuszczkiewicz (1828-1900) - polski malarz, historyk sztuki. Vide: Jolanta Polanowska, „Władysław Łuszczkiewicz”, w Słownik artystów polskich i obcych w Polsce działajaccych. Malarze, rzeźbiarze, graficy, t. 5, red. Janusz Derwojed (Warszawa: Krąg, 1993), 204-209.

14 Feliks J.N. Szynalewski (1825-1892) - polski profesor, malarz. Vide: Grażyna Gzella, „Szynalewski Feliks Jan Nepomucen”, w Polski Słownik Biograficzny, t. 50, red. Andrzej Romanowski (Warszawa-Kraków: Polska Akademia Umiejętności, 2015), 192-195.

15 O fenomenie kulturowym Kołomyi tego okresu, jej rozwoju i niezwykłym znaczeniu dla regionu, bardzo trafnie napisał prof. Stanisław Nicieja. „W XIX wieku złośliwi szydercy ukuli inne powiedzonko: «Anglik z Kołomyi». Miało ono charakteryzować prowincjusza udającego światowca: imitacja blichtru, słoma w butach, ale na głowie najlepszy markowy kapelusz. Ten lekceważący ton, który dawał się słyszeć w głosie warszawiaka, lwowiaka czy krakusa, był jednak wyrazem wyjątkowej ignorancji, bo Kołomyja nie była zapyziałą, ponurą prowincją w Austrii, a później w Polsce. Dzięki odkryciu w 1879 roku obfitych złóż ropy naftowej w Słobodzie Rungurskiej powstało tam setki szybów, które do Kołomyi ściągnęły kapitał angielski. A razem z nim rzeszę autentycznych londyńskich dandysów i dżentelmenów. Anglik z Kołomyi z grubym portfelem w kieszeni był marzeniem każdego sklepikarza, hotelarza czy właściciela pensjonatu od Krynicy po Truskawiec, od Kosowa po Zakopane". Stanisław Sławomir Nicieja, Kresowa Atlantyda. Historia i mitologia miast kresowych: Kołomyja, Żabie, Dobromil, t. 4 (Opole: Wydawnictwo MS, 2014), 10. 
Ryc. 2. Widok budynku szkoły garncarskiej w Kołomyi - pocztówka XIX w.

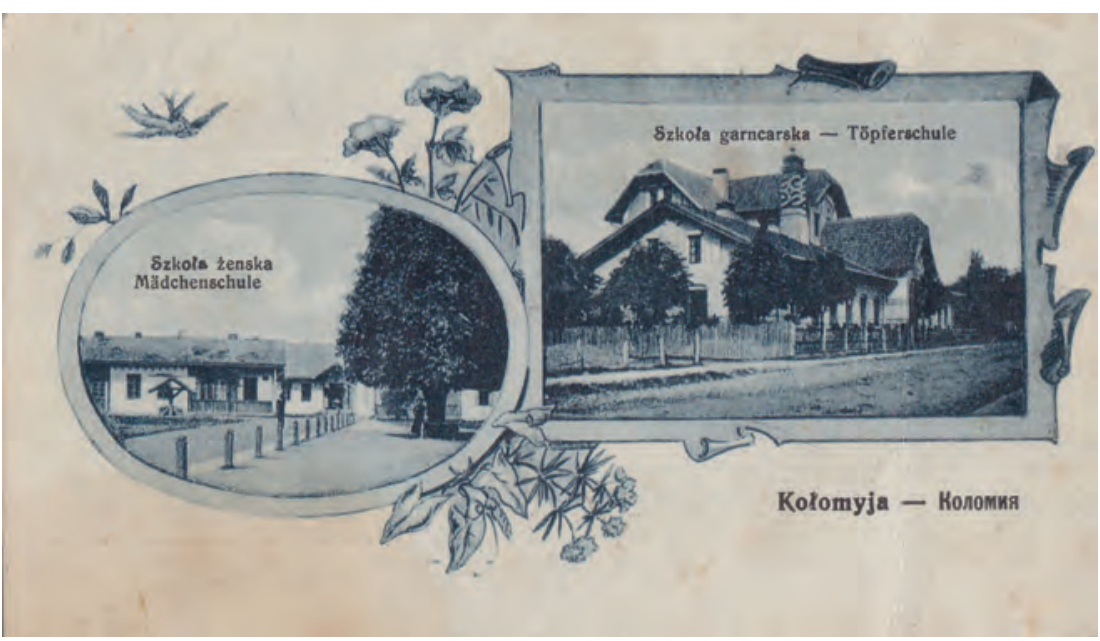

Źródło: https://artkolo.org/

Ryc. 3. Nauczyciele i uczniowie Szkoły Garncarskiej w Kołomyi

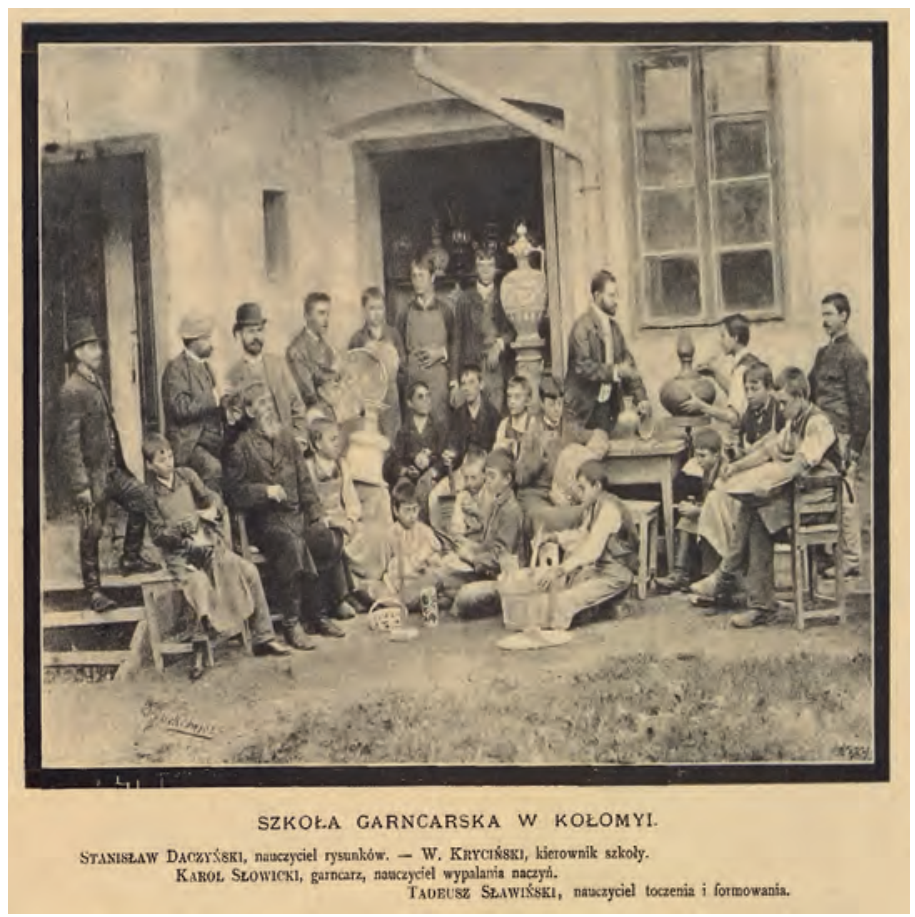

Źródło: Mardyrosiewicz, „Szkoła Garncarska w Kołomyi”, 229. 


\subsection{Perypetie młodego malarza}

Daczyński już po kilku latach pracy jako nauczyciel rysunku, nie mając jednak ustabilizowanej sytuacji materialnej, zdecydował się na wejście w związek małżeński. Jego wybranką została mieszkanka pobliskiego miasteczka Kosowa, czy jak wówczas pisano Kossowa - panna Stefania Zajączkowska ${ }^{16}$. Ślub odbył się 26 kwietnia 1890 r. w Kosowie, w kościele parafialnym obrządku łacińskiego pw. Matki Boskiej Różańcowej. Młodzi zamieszkali w Kołomyi, natomiast ze względu na bliskość do Kosowa byli zapewne częstymi gośćmi w rodzinnym mieście małżonki Daczyńskiego. Pobyty w tym urokliwym miasteczku stanowiły też inspirację dla artysty, gdyż zostawił kilka szkiców z Kosowa ${ }^{17}$, ale też i obrazów, które znane są ze zbiorów publicznych i prywatnych. Przedstawiał na nich portrety Hucułów z okolic Kosowa, panoramę gór czy też zwierzęta domowe na górskich łąkach.

Leżący w kotlinie Rybnicy Kosów był o wiele ładniejszą okolicą dla wrażliwego na piękno malarza niż Kołomyja, która mogła zachwycić tylko w czasie jarmarków czy innych zgromadzeń lub świąt. Jak dowiadujemy się z zaproszenia, błogosławieństwa młodej parze, zapewne w zastępstwie rodziców pana młodego, mieli udzielać państwo Krycińscy. Nie mamy podstaw, by założyć, że stało się inaczej. Nie mamy też wiadomości o tym, jak układało się pożycie młodych małżonków. W każdym razie Stanisław - poza pracą w szkole - starał się dorabiać, malując obrazy. Zresztą większość z tych najbardziej znanych pochodzi właśnie z tego okresu' ${ }^{18}$.

Daczyński pracował jako nauczyciel rysunku i z pewnością czynił starania, by zostać pełnoprawnym nauczycielem szkoły, co zresztą było zrozumiałe. Pensja nie była zbyt wielka, ale dawała szanse na pewną stabilizację. Starając się o posadę, musiał wykazywać się aktywnością. W 1894 r. - jako nauczyciel i opiekun - uczestniczył w wystawie we Lwowie, na której przedstawione zostały osiągnięcia szkoły w Kołomyi. Za tę pracę dostał list pochwalny $\mathrm{z}$ wydziału krajowego ${ }^{19}$. Być może nie było to nadzwyczajne wyróżnienie, jednak dawało mu pewien argument $w$ ubieganiu się o uzyskanie pełnego zatrudnienia w Kołomyi, a gdyby chciał szukać pracy w innym miejscu, był to pewnego rodzaju list rekomendujący.

16 Stefania z Zajączkowskich Daczyńska - ur. 01.01.1871 w Kosowie - zm. 25.03.1923 w Krakowie.

17 Vide: Duda, „Pokuckie i huculskie inspiracje”, 22.

18 Vide: ibidem.

19 Archiwum Prywatne Autora [APA], List Wydziału Krajowego we Lwowie do Stanisława Daczyńskiego, L.848, rkps, Lwów 22.02.1895, odpis: Nowy Targ 6.12.1920. 
Ryc. 4. Zaproszenie na ślub Stefanii Zajączkowskiej i Stanisława Daczyńskiego

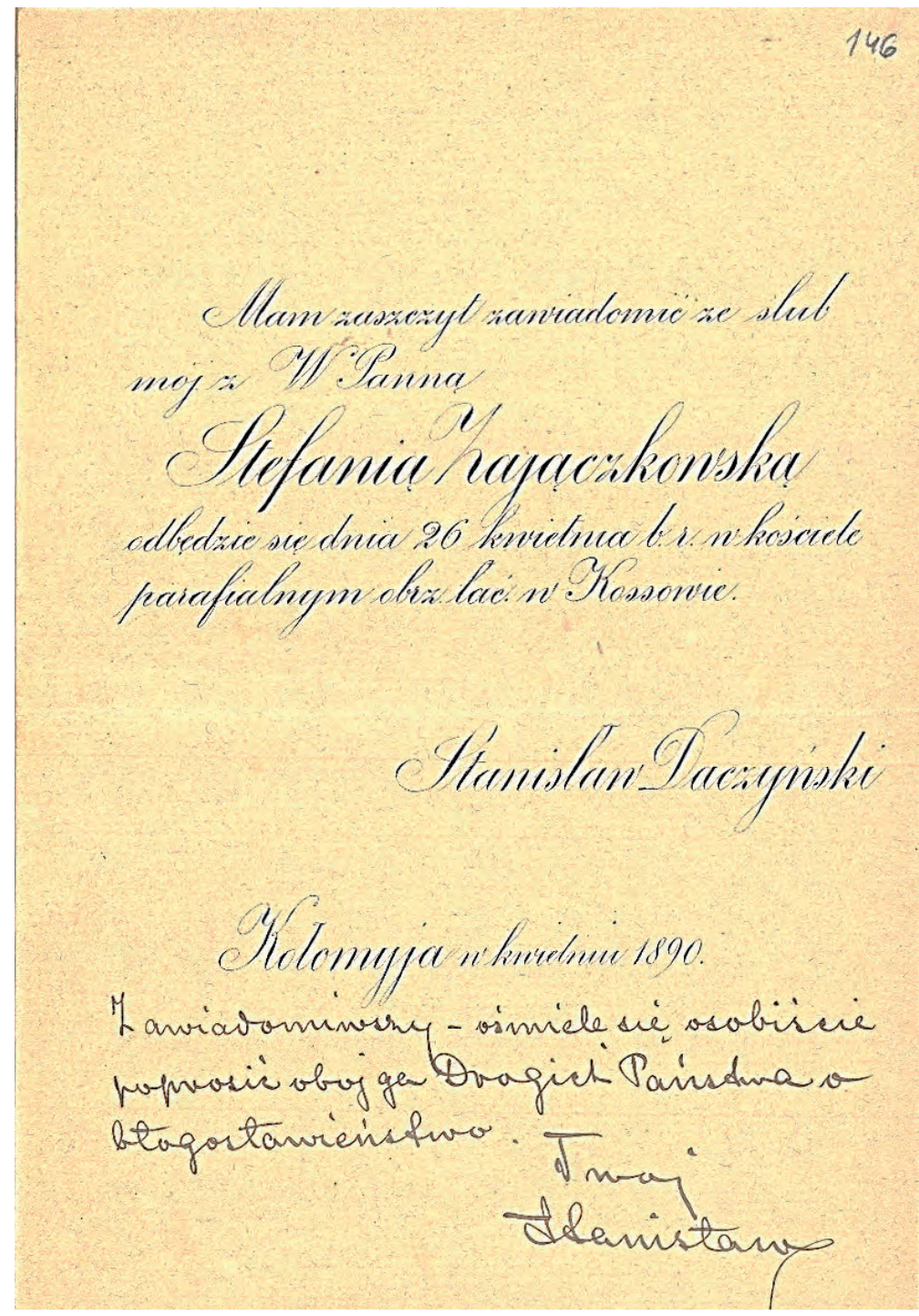

Źródło: Archiwum Uniwersytetu Jagiellońskiego. 
Ryc. 5. S. Daczyński - Szkic do portretu kobiety - rys. ołówkiem

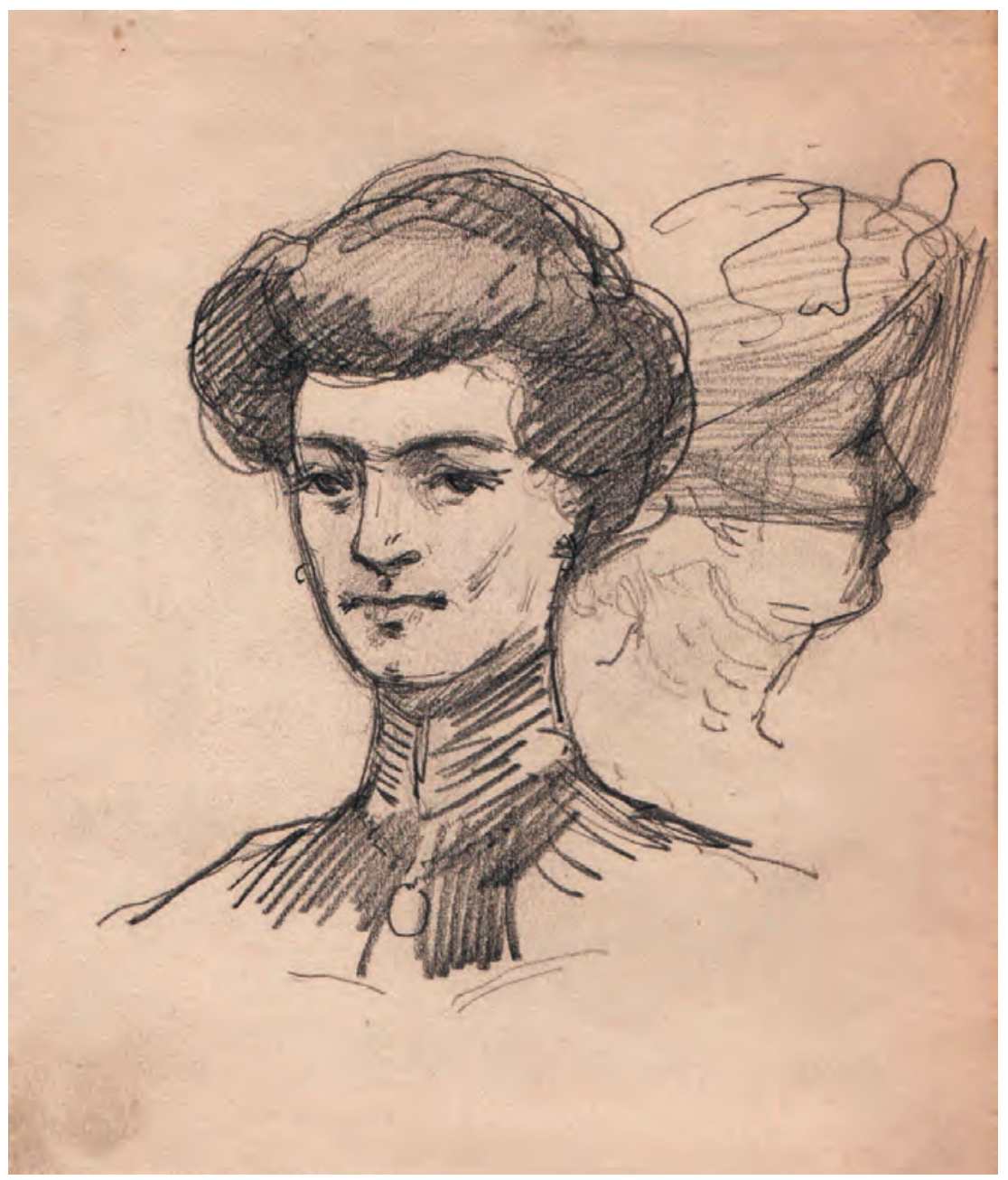

Źródło: zbiory autora.

Daczyński dopiero od 1 stycznia 1897 r. stał się pełnoprawnym etatowym nauczycielem w Kołomyi ${ }^{20}$. I w tym miejscu należy się czytelnikowi sprostowanie, a właściwie doprecyzowanie informacji. W przywoływanej już publikacji podany został rok 1896, co podyktowane zostało informacją prasową. Dokumenty, które udało się pozyskać, wskazują, że nastąpiło to 6 lutego 1897 r., kiedy to Wydział Krajowy Królestwa 
Galicji i Lodomerii z Wielkim Księstwem Krakowskim mianował Stanisława Daczyńskiego „stałym nauczycielem rysunku w Krajowej szkole garncarskiej w Kołomyi z płacą tysiąca dwustu (1200) zł”21. Kwota była wynagrodzeniem rocznym. Drugą ważna decyzją było to, że okres, który zaliczany będzie Daczyńskiemu do emerytury, postanowiono liczyć od 1890 r. Decyzję wydział krajowy przekazał Daczyńskiemu 13 marca 1897 r. Daczyński - co zostało należycie odnotowane - złożył także przysięgę. Nastąpiło to 1 kwietnia $1897 \mathrm{r}^{22}$, a co za tym idzie, z pewnością otrzymał również zapowiedziane wynagrodzenie, i to $\mathrm{z}$ wyrównaniem od 1 stycznia tegoż roku.

Niewątpliwie dało mu to pewien komfort życia, ale pociągało za sobą także sporo większych obowiązków, zwłaszcza formalnych, związanych z prowadzeniem zajęć i sprawozdaniami ze swojej pracy.

Wracając jednak do wątku związanego z relacją Daczyńskiego z Krycińskim, to niestety wspólna praca obu artystów trwała tylko do $1898 \mathrm{r}$. Kryciński przeniósł się wówczas do Lwowa, gdzie - w c.k. Państwowej Szkole Przemysłowej ${ }^{23}$ - objął funkcję profesora rysunku ${ }^{24}$, jednak oficjalną rezygnację z pracy w Szkole Garncarskiej w Kołomyi złożył 15 sierpnia 1890 r. Rezygnacja Krycińskiego podyktowana była niechęcią nie tyle do pracy w Kołomyi, ile do systemu szkolnictwa, które zakładało, że dyrektor szkoły będzie jednocześnie administrował i pracował jako kancelista, a może także jako księgowy lub nawet pracownik fizycz$n y^{25}$. To niedocenienie pracy nauczyciela widoczne jest także w listach Daczyńskiego do Krycińskiego.

21 APA, List c.k. Wydziału Krajowego we Lwowie do Stanisława Daczyńskiego L. 14.944, rkps, Lwów 13.03.1897.

22 Ibidem.

23 Szkoła powstała w $1890 \mathrm{r}$.

24 „Rozporządzeniem z dnia 22. października 1898 L. 27.167 zawiadamia c. k. Rada szkolna krajowa, że c. k. Ministerstwo W. i Ośw., reskryptem z dnia 11. października 1898 L. 14.219 zamianowało c. k. profesora gimn. w Kołomyi, p. Waleryana Krycińskiego, profesorem dla rysunków wolnoręcznych i malarstwa dekoracyjnego w tutejszym zakładzie". Siódme sprawozdanie c.k. Państwowej Szkoły Przemysłowej we Lwowie za rok szkolny 1898/99 (Lwów: Państwowa Szkoła Przemysłowa, 1899), 3.

25 O rezygnacji Krycińskiego z pracy w szkole garncarskiej pisał następująco Bohdan Mardyrosiewicz: „Zakres nauki szkolnej został znacznie powiększony; czynności kierownika wymagały coraz więcej czasu; inwentarz, którego wartość obliczono przy odbiorze szkoły na rzecz kraju na 1154 złr. powiększył się przeważnie pracą nauczycieli tak, że wartość jego w roku 1890 obliczono na około 6000 złr. Zebrane wyroby miejscowych garncarzy, okazy prac szkolnych z różnych epok, jako też wyroby zagraniczne (jako zawiązek przyszłego muzeum ceramicznego szkoły), modele rysunkowe, wzory naczyń, projekty i zbiór motywów ornamentacyjnych, wszystko to potrzebuje obszerniejszego i wygodniejszego umieszczenia. Siły nauczycielskie - przy tak rozległej działalności szkoły - nie wystarczały także; trzeba było osobnego nauczyciela do chemii 
Daczyński już początkiem 1899 r. pisze do niego do Lwowa, skarżąc się na panujące w szkole zasady i na niesprawiedliwość związaną z wynagradzaniem pracowników. Ma oczywiście na myśli siebie. Oto co napisał:

Kochany Walery! Dużo mam pisać. Wczoraj wniosłem podanie o uwolnienie mię z funkcji pomocnika dyżurnisty kancelaryjnego. Komitet załatwił przychylnie, natomiast zaproponował Wydz. Kraj. bym uczył rys. geometr. i konstrukcyjnych - a na pomoc kancelaryjną wstawił w budżecie $20 \mathrm{fl}$. miesięcznie. Widzisz Kochany - to ja nie byłem wart, by przy mojej pracy dostać za ubiegły rok o $20 \mathrm{fl}$. więcej - dopiero dla nowego funkcyonaryusza będą grosze - a za ubiegly upiekła się „durniczka”26.

Na tym stwierdzeniu skarga Daczyńskiego się nie kończy. Za wielką ujmę uznaje przyznanie nowemu dyrektorowi - Aleksandrowi Klimaszewskiemu ${ }^{27}$ - dodatku do mieszkania w wysokości 300 florenów.

Rzeczywiście Daczyński musiał dość kiepsko funkcjonować, gdyż prosi Krycińskiego o pomoc finansową. W dalszej części listu wyrażał to w słowach:

i technologii, modelatora, jeszcze jednego nauczyciela rysunków, kaflarza specyalistę i palacza, jeżeli szkoła miała dalej rozwijać się pomyślnie. Dozór tak licznego personelu, administracya, szczególnie warsztatowa, połączona z obszerną korespondencyą, wymagały stałego kierownika, który by cały czas swój poświęcić mógł sprawom szkoły. A ponieważ p. Kryciński, zatrudniony w gimnazyum, nie mógł podołać wszystkiemu, a zwłaszcza część administracyjna odrywała go od pracy fachowej artystycznej, której z zamiłowaniem się oddaje, dowiedziawszy się, że Wydział krajowy nie ma zamiaru «systemizować» posad w szkole kołomyjskiej - postanowił - nie chcąc być na przeszkodzie prawidłowemu rozwojowi, powołanego na nowo do życia zakładu - usunąć się z posady kierownika. Przedstawiwszy przeto za porozumieniem się z kuratorem i komitetem miejscowym projekt dalszej organizacyi, wniósł zarazem swoją rezygnacyę w dniu 15 sierpnia 1890, pozostawiając jako owoc swej działalności naprawioną reputacyę szkoły, zdolnych nauczycieli z byłych uczniów, unormowany plan nauk, powiększony inwentarz, a przede wszystkiem kilkaset wzorów form i dekoracyj tak w naczyniach, jako też w rysunkach z dekoracyą miejscową. Wydział krajowy, wyraziwszy uznanie p. Krycińskiemu za jego gorliwą działalność, przyjął rezygnacyę, mianując na jego miejsce - za staraniem kierownika doświadczalnej stacyi ceramicznej p. Edmunda Krzena - byłego ucznia chemii na technice lwowskiej, p. Aleksandra Klimaszewskiego. Profesor Kryciński usunąwszy się konieczności od kierownictwa szkoły garncarskiej, nie przestał wszelakoż pracować dalej na polu dekoracyi ceramicznej; owszem cały wolny czas poświęca tej pracy. I tak na ostatnią wystawę szkiców we Lwowie wysłał trzy wspaniałe wazy, projektowane i malowane własnoręcznie. A obecnie przygotowuje do reprodukcyi, jako owoc dziesięcioletnich studyów w kierunku dekoracyi garncarskiej w Kołomyi publikacyę p.t. «Wzory form i dekoracyj naczyń z motywów ludowych na Pokuciu»”. Mardyrosiewicz, „Szkoła Garncarska w Kołomyi”, 333-334.

26 Korespondencja Waleriana Krycińskiego z lat 1874-1928, t. 1: A-H, 148-149.

27 N.N. 
$\dot{z} y c ́$ przy długach coraz ciężej - nawet nie ma czasu i zarobić co przy sztalugach - bo $i$ wakacji ja nigdy nie mam ani Świat, a przynajmniej już trzeci rok - bo zawsze zastępstwa. Tak było i ostatnim razem. Wierzaj, że to wszystko razem $\mathrm{z}$ administracją, rachunkami i inwentarzem tak mi zbrzydło, że gdybym był kawalerem, to dziś bym plunął na całą służbę. Czy my się doczekamy polepszenia płac kiedy - nie wiem - wiem tylko tyle, że kierownik będzie pobierał tego roku $2000 \mathrm{fl}$., bo [... $]^{28}$ i dodatek na mieszkanie, a ponieważ ma swój mająteczek, nie może dychać. Żałuję bardzo, że nie umię po rosyjsku, pojechałbym tam i zaraz dostał miejsce przy tamże się organizujących szkołach keramicznych - 2500 rubli. W tej materii jeździ tu prof. Uniwersytetu Odeskiego - Niemiec - a raczej Czech - zwiedzał nasz zakład - informował się - pojechał dalej do Wiednia.

Walerku ten stary żyd mię ciśnie - czy nie można co posłać - bo powiadam $\mathrm{Ci}$, że mię chcą zjeść żywcem. Bronię się jak mogę i umię, obiecuję złote interesa - ale to nie długo pociągnie. Zmiłuj się i zaradź $\mathrm{CO}^{29}$.

Możemy przypuszczać, że relacje Daczyńskiego z nowym kierownictwem szkoły nie układały się zbyt pomyślnie. Widać jego rozżalenie, ale też świadomość tego, że traci wsparcie w lokalnej społeczności, które osoba Krycińskiego mu gwarantowała. Co więcej, był przez nową władzę szkoły postrzegany jako człowiek poprzednika. Nawet gdyby był bardzo lojalny, to i tak pewnie nie pomogłoby mu to w stworzeniu poprawnych relacji. Trzeba także pamiętać, że społeczeństwo tego okresu ma charakter stanowy, a zatem skoro nowy kierownik szkoły - jak pisze Daczyński - posiadał „swój mająteczek”, to ubogi - choć wykształcony - artysta nie był dla niego partnerem.

Ciekawostką wydaje się informacja Daczyńskiego o rosyjskim profesorze, który był albo Niemcem, albo Czechem, jak on to relacjonuje. Nie było to jednak nic nadzwyczajnego, ponieważ zainteresowanie sztuką huculską w carskiej Rosji było bardzo wczesne. Już w 1867 r. odbyła się wystawa sztuki Hucułów, Bojków i Łemków w Moskwie ${ }^{30}$. Tym samym wyprzedzała lwowską wystawę o równe dziesięć lat, a słynną wizytę cesarza austriackiego na wystawie w Kołomyi o lat trzynaście. Zatem i zainteresowanie Rosjan sztuką garncarską było znaczne. Ten olbrzymi kraj miał z pewnością tak ogromne potrzeby w zakresie konsumpcji nawet zwyczajnej ceramiki, że praca dla naszego artysty mogłaby też się znaleźć.

Zapewne perypetie obydwóch malarzy miały już wcześniejszy początek, gdyż Daczyński w tym samym liście daje znać Krycińskiemu, że

28 Wyraz nieczytelny.

29 Korespondencja Waleriana Krycińskiego z lat 1874-1928, t. 1: A-H, 149.

30 Vide: Maria Brzezina, Stylizacja huculska (Kraków: Universitas, 1992), 52. 
jego artykuł -publikowany w lokalnej prasie - narobił w Kołomyi nieco „huczku”31. Być może Kryciński, mając już nową posadę, wytykał błędy i niedociągnięcia nadzorującej c.k. Komisji, od której zależało funkcjonowanie szkoły. Niewątpliwie, musiał znać doskonale sytuację, w której znajdował się Daczyński. On zaś, w końcowej części listu, poinformował Krycińskiego, że do sprzedaży jest „garnitur na umywalnię”, w skład którego - jak pisał - wchodziło osiem elementów, tj.: „dzbanek, cylinderek, miseczka na gąbkę i cztery pudełka na mydło i proszki [...]"32. Gdyby to przeliczyć, to w żaden sposób osiem sztuk nie wychodzi. Być może zapomniał o czymś, a być może - w ferworze pisania emocjonalnego listu - po prostu pomylił się w rachunkach. Niemniej jednak - z przyjacielską uczciwością - informuje Krycińskiego, żeby ten nie kupował w ciemno, natomiast dopiero wówczas, gdy się mu spodoba, to może dokonać zakupu ${ }^{33}$.

Jedenaście dni po pierwszym liście - 20 lutego 1899 r. Daczyński pisze następny. Ma on zupełnie inny ton, bo też i problematyka w nim podniesiona ma rangę ponadprzeciętną. Dowiadujemy się, że kilka dni wcześniej Daczyński otrzymał od Bohdana Mordyrosiewicza ${ }^{34}$ list Krycińskiego, w którym ten zgłaszał swoją kandydaturę do sejmu ${ }^{35}$. W korespondencji Daczyński natychmiast wskazał Krycińskiemu jego potencjalnych konkurentów, o których mówiło się jako możliwych kandydatach. Jednocześnie zadeklarował mu pełną lojalność, nie szczędząc przy tym bardzo racjonalnych uwag. Wyraził to w następujących słowach:

My - to jest wszyscy Twoi przyjaciele - wierzymy, i jesteśmy przekonani o Twoich dobrych chęciach służenia Krajowi - a to przez pewną znajomość spraw przemysłowych, szkolnych etc., którą trzeba rozwinąć lub dźwignąć z apatyji i upadku, ale do tych dobrych chęci trzeba jeszcze i pieniędzy. Jak mówiliśmy razem z Mordyrosiewiczem, potrzeby na przeprowadzenie wyboru kandydata naszego minimum 2000fl., a znając Twe obecne stosunki wiem, że takiej sumy nie możesz zaryzykować na rezultat niepewny.

Nie ma tu mowy o kupowaniu głosów lecz na czynności przygotowawcze, a jak ci gębacze, z któremi się trzeba liczyć, bo każdy z nich ma za sobą kilkudziesięciu, a żaden $\mathrm{z}$ nich nawet dla najlepszej sprawy nie będzie za darmo gardłował i swoich przeciągał. Zresztą byłeś tu tyle lat, znasz nasze

31 Ibidem.

32 Ibidem.

33 Ibidem.

34 Bohdan Mordyrosiewicz - publicysta pochodzenia ormiańskiego.

35 Korespondencja Waleriana Krycińskiego z lat 1874-1928, t. 1: A-H, 150. 
mieszczaństwo, to wiesz dobrze o tem, że za chęć służenia dobrze krajowi trzeba jeszcze zapłacićc ${ }^{36}$.

Ryc. 6. Fotografia Waleriana Krycińskiego

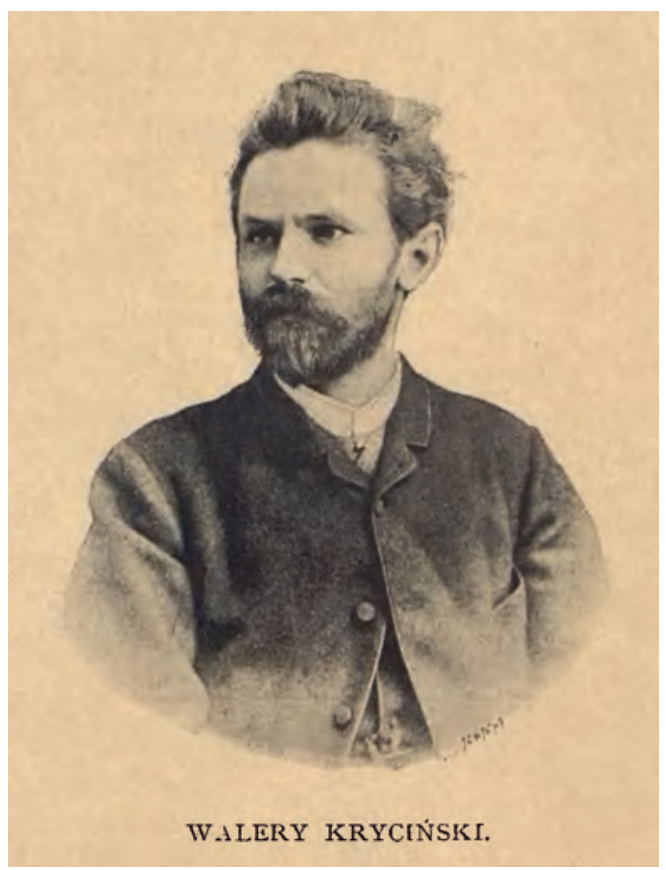

Źródło: Mardyrosiewicz, „Szkoła Garncarska w Kołomyi”, 331.

Kampania wyborcza jednak kosztuje. Daczyński wprawdzie odżegnuje się od - katastroficznej dla I Rzeczypospolitej - metody kupowania głosów wśród „panów szlachty” na sejmikach i sejmach, jednak jest świadom, że nawet kampania mówiona musi być poparta środkami finansowymi. $Z$ jednej strony można uznać, że jest to oczywiste, z drugiej pokazuje jednak, że środowisko kołomyjskie nie było zbyt zainteresowane zmianami, które mogłyby nie przynieść im wprost zysku. Być może był to też wynik rewolucji przemysłowej w tym mieście, która uświadomiła mieszkańcom, że wszystko ma swoją cenę i wszystko może być na sprzedaż. To zaś, co nieprzeliczalne na żywą gotówkę, jest niewarte zachodu. Trzeba też pamiętać, że środowisko polskie było w tym regionie Galicji w zdecydowanej mniejszości w stosunku do pozostałych narodowości, co też nie dawało zbyt wielkich szans na zebranie właściwej liczby głosów. 
Mając na uwadze potencjalny problem z zapewnieniem środków na kampanię wyborczą, Daczyński proponuje Krycińskiemu, by - ewentualnie - znalazł „możnego mecenasa”, który byłby w stanie wyłożyć środki finansowe na promocję jego kandydatury w terenie. W dalszej części korespondencji wyraża - zapewne bardzo szczere - przekonanie, że wybór Krycińskiego byłby bardzo potrzebny dla Kołomyi, ale też i on osobiście - gdyby wybór doszedł do skutku - byłby z tego bardzo dumny. Cieszyłby się, widząc, jak Kryciński ,jako prof. i malarz zasiada na ławie poselskiej”37. Po zakończeniu wywodu dotyczącego potencjalnych kosztów kampanii, którą miałby Kryciński przeprowadzić, Stanisław Daczyński przechodzi - jak zwykle - do własnych problemów. Są one prozaiczne, ale dla niego znaczne. Ciągle żyje z pożyczek, a niestety są one kosztowne, bankier - „franca bierze 48\%"38. Tym razem jednak nie wnioskował o jakąś zaliczkę u Krycińskiego, ale zapowiedział się na święta we Lwowie. Jak napisał: „to się zobaczymy i niejedno można uradzić” ${ }^{39}$. Nie mamy żadnych informacji o tym, że Kryciński zdecydował się ostatecznie kandydować do sejmu krajowego, a już z pewnością nie został wybrany. Daczyński zapewne dotarł do Lwowa i obaj panowie mogli omówić dalsze działania. Niemniej jednak ich problemy nie skończyły się wraz z tym spotkaniem.

\subsection{Listy Stanisława Daczyńskiego z XX w.}

W zachowanej korespondencji między dwoma artystami malarzami nastąpiła znaczna przerwa. Można przypuszczać, że nie była realną przerwą w relacjach między nimi, a jedynie nie mamy o ich wzajemnych kontaktach wiadomości. Być może listy zaginęły lub zostały gdzieś indziej przekazane. Daczyński zapewne w tym czasie pracował na utrzymanie swojej rodziny, co - jak wiemy już i z listów do Böhma, i z listów do Krycińskiego - nie było łatwe. Trzeba zaznaczyć, że pewien rozgłos przyniosło mu umieszczenie wyrobów wykonanych pod jego kierownictwem na Wystawie Światowej w Paryżu w roku 1900. Wyroby ceramiczne z kołomyjskiej szkoły zdobiły pawilon galicyjski ${ }^{40}$.

\footnotetext{
37 Ibidem.

38 Ibidem.

39 Ibidem.

40 Vide: Aneta Borowik, Dzieje, architektura oraz twórcy Zakładu OO. Jezuitów w Chyrowie: Twórczość Antoniego Łuszczkiewicza oraz Edgara Kovátsa na tle epoki (Katowice: Wydawnictwo UŚ, 2012), 189.
} 
W każdym razie nowe materiały archiwalne rozpoczyna list z 20 maja 1904 r. Ton, w którym Daczyński odnosi się do Krycińskiego, nie wskazuje w żadnym wypadku, by była to nowa odsłona kontaktów między nimi. Można mieć wrażenie, że jest to jedynie podnoszenie nowych tematów, jakby chwilę temu zakończonych. Tym razem do Daczyńskiego zwrócił się przełożony zakonu oo. jezuitów, którzy będąc w Kołomyi od 1895 r., wybudowali kościół, nie został on jednak w pełni wykończony i wyposażony ${ }^{41}$. Problem, z którym zetknął się Daczyński, dotyczył malowania i złożenia całego ołtarza w nawie głównej świątyni. Jezuici z pewnością zwrócili się do niego, ze względu na to, że wcześniej - wraz z Krycińskim - wykonał polichromię w grekokatolickiej cerkwi pod wezwaniem św. Mikołaja w Kołomyi ${ }^{42}$.

Jak relacjonował w dalszej części listu do Krycińskiego, jezuici mieli wprawdzie wycenę pracy, którą w formie oferty wniósł miejscowy malarz Orzechowski ${ }^{43}$, widać jednak, że nie byli przekonani do tego, czy mu ją zlecić; być może szukali bardziej znaczącej w środowisku osoby. Tak czy

41 O funkcjonowaniu zakonu jezuitów i losach ich kościoła w Kołomyi tak napisał badacz dziejów miasta Ryszard Brykowski: „Kościół pojezuicki p.w. św. Ignacego Loyoli (obecny parafialny rzymskokatolicki p.w. Matki Boskiej Częstochowskiej). OO. Jezuici zaproszeni zostali do Kołomyi przez Gminę Miejską w 1895 r., tymczasową kaplicę p.w. św. Ignacego Loyoli i rezydencję otwarto 29 IX 1895 r. Kamień węgielny poświęcono 2 VIII 1896 r., kościół ukończono w stanie surowym 31 XI 1897 r., prace wykończeniowe trwały zapewne do $1905 \mathrm{r}$, (data na dawnej chorągiewce wieńczącej hełm wieży). Po 1946 r., kościół zostaje zamknięty, z czasem zamieniony na magazyn meblowy; przed frontonem kościoła wzniesiono budynek bezpośrednio z nim połączony z przeznaczeniem na sklep meblowy. Odzyskany w 1990 r., konsekrowany 3 XI 1990 r., od tego czasu stopniowo restaurowany m.in. przy pomocy kołomyjan z kraju i rozproszonych po świecie oraz przy pomocy Stowarzyszenia «Wspólnota Polska»; cześć budynku sklepowego bezpośrednio połączona z kościołem rozebrana w 1998 r. Neogotycki, o jednowieżowej elewacji frontowej zbliżonej do elewacji kościoła w Otyni. Murowany. Wewnątrz zachowane, mocno zniszczone, malowidła ścienne: w prezbiterium starsze, być może sprzed 1914 r., o motywach architektoniczno-dekoracyjnych (iluzjonistyczne pilastry, marmoryzacja, monogramy Marii, sklepienia ciemnobłękitne ze złotymi gwiazdkami); w korpusie nawowym z ok. 1930 r. o charakterze ornamentalno-roślinnym, wykonane przez malarza Wacława Jakuba Jeziorko z Bochni (1859-1935), osiadłego w Kołomyi. W głębi, na osi kościoła rezydencja oo. Jezuitów, wzniesiona od sierpnia 1901 r. do października 1902 r. Przed 1939 r. pomiędzy kościołem a budynkiem rezydencjalnym biegła aleja z rozarium po bokach. Obecnie budynek użytkowany jako szpital zakaźny", Ryszard Brykowski, Kołomyja: jej dzieje, zabytki (Warszawa: Wydawnictwo Indruk, 1998), 71-73.

42 Vide: Aleksandra Melbechowska-Luty, „Daczyński Stanisław Leopold Maksymilian”, w Słownik artystów polskich i obcych w Polsce działających. Malarze-rzeźbiarze-grafi$c y$, t. 2, red. Jolanta Maurin-Białostocka et al. (Wrocław-Warszawa-Kraków-Gdańsk: Wydawnictwo Ossolineum, 1975), 1.

43 Adolf Orzechowski - polski malarz, pozłotnik. Prowadził pracownię artystyczną i malarską w Kołomyi na ul. Bańkowskiego 13. Wraz z Wacławem Jakubem Jeziorką z Bochni malował w 1909 roku kościół w Kutach. Vide: Sprawozdanie z działalności Ligi 
inaczej Daczyński nie był w stanie odpowiedzieć na postawione przez nich pytanie dotyczące tego, czy kwota - „której żąda za wygruntowanie, namalowanie i złożenie tego ołtarza $2500 \mathrm{fl}$ ”44 - jest właściwa za taki rodzaj pracy. Daczyński, który - jak stwierdził w dalszej części korespondencji do Krycińskiego - sam o wycenie takiej pracy nie miał pojęcia, skierował ją do niego jako specjalisty w tej materii. Gdyby zaś ten nie mógł wycenić tej pracy na podstawie wysłanego rysunku, to dobrze by było, żeby „mógł kogo polecić, coby sam na własne ryzyko przyjechał i zobaczył, czy warto tę sprawę traktować” ${ }^{45}$. Istotną uwagą, którą przesłał Krycińskiemu, była informacja, że jezuici mają drewno do wykonania konstrukcji, jednak ze względu na to, że leżało na wolnym powietrzu, niestety nie nadaje się ono już do użycia.

Wspomina też, że do wykonania tej pracy był proponowany - bardzo rekomendowany przez Alfreda Zachariewicza ${ }^{46}$ - niejaki Kucharski ${ }^{47}$, widać jednak Daczyński nie był przekonany, by zaproponować tę kandydaturę jezuitom. Jak donosił w dalszej części korespondencji, sam nie był zainteresowany wykonaniem tej pracy, jednak chciał, by podjął się jej ktoś, kogo mógłby ewentualnie polecić Kryciński. Daczyński - zapytując, czy Krycińscy będą w wakacje we Lwowie - zapowiedział się tam z wizytą w czerwcu, licząc przy tym, że uda się im spotkać i spokojnie porozmawiać.

Pomocy Przemysłowej za czas od 15. sierpnia 1908, do 31. grudnia 1909, t. j. za szósty rok istnienia (Lwów: Liga Pomocy Przemysłowej, 1910), 258.

44 Korespondencja Waleriana Krycińskiego z lat 1874-1928, t. 1: A-H, 153.

45 Ibidem.

46 Alfred Zachariewicz (1871-1937) - polski architekt, syn Juliana Zachariewicza. Autor projektów wielu budynków i mostów. Vide: Igor Żuk, Julian Zachariewicz 1837-1898, Alfred Zachariewicz 1871-1937: wystawa twórczości. Katalog (Warszawa: Stowarzyszenie Architektów Polskich Oddział Warszawski, 1996), 6-12.

47 N.N. 
Ryc. 7. S. Daczyński - Ołtarz w Kościele oo. Jezuitów w Kołomyi 1901-1904 Kołomyja 1904 rok - szkic tuszem

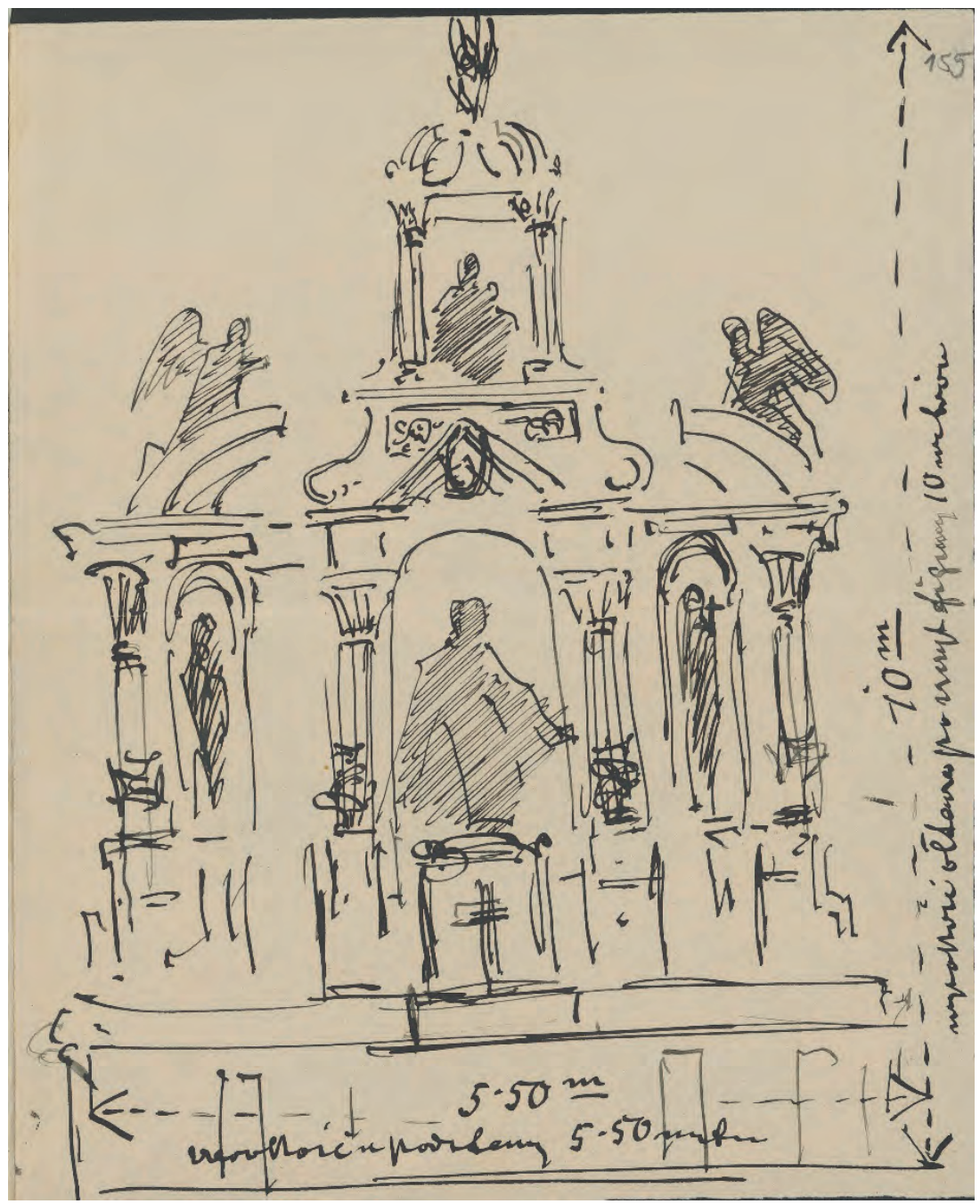

Źródło: Archiwum Uniwersytetu Jagiellońskiego.

Następny z listów ma datę 5 lutego 1906 r. Jego treść jest zupełnie inna niż poprzednich. Daczyński z radością odnosi się do prezentu, który przesłał mu Kryciński, czyli swojej fotograficznej podobizny. Daczyński nie szczędzi mu komplementów, zwłaszcza dotyczących bujnych włosów. Sam ze smutkiem stwierdza, że już prawie zupełnie posiwiał, jednak 
ważne, by „zawsze młode było - serce" ${ }^{\text {" }}$. Nie mniej ciekawa jest jednak propozycja, na którą Daczyński odpowiada przyjacielowi. Dotyczy mianowicie zrobienia całościowej wystawy dzieł Daczyńskiego. W odpowiedzi na zapewne kuszącą propozycję odpisał:

co do wystawy zbiorowej, to może się kiedyś na nią zdobędę, bo na razie to trudno by mi było obrazy, które są w różnych stronach pozbierać, więc trzeba by nowe namalować, albo jak dostanę „łopatą w grzbiet”, to może znajdzie się jakaś uczynna dusza i tę szopkę urządzi. Tak jak obecnie, to wyznam Ci otwarcie, że nie pamiętam bym który tak namalował bym był z niego zupełnie zadowolonym. Wiecznie się znajdzie coś takiego, co chciałbym po niewczasie przemalować ${ }^{49}$.

Co zaś do malowania nowych obrazów, to też jest sceptyczny, gdyż na oddawanie się swojej profesji ma czas tylko w wakacje. Codzienna nauka oraz lekcje, które dawał dodatkowo uczniom w Kołomyi, nie pozwalały mu na to, by „złapać czas na jakiś «seans» malarski” ${ }^{50}$. Z nieukrywaną radością informuje też Krycińskiego, że decyzją władz oświatowych ma się wybrać do Lwowa, by w Szkole Przemysłowej podnieść swoje kwalifikacje. Wprawdzie - jak pisze - „umię cokolwiek rysować, ale pogląd nie zawadzi, a przy tem będę miał okazję Was zobaczyć i uściskać"51. List - jak to było w zwyczaju - Daczyński kończy serdecznymi pozdrowieniami dla znajomych i rodziny Krycińskiego.

Daczyński w nie dość szybkim tempie zrealizował swoją zapowiedź przyjazdu do Lwowa. List, który wysłał do Krycińskiego, nosi datę 30 marca 1907 r., ale jest ściśle powiązany z poprzednim. Kołomyjski malarz dotarł bowiem do Szkoły Przemysłowej i odbył zlecony kurs. W liście przeprasza Krycińskiego, że nie udało się mu w ostatnim dniu odwiedzić go w mieszkaniu ${ }^{52}$. Niestety zbyt długo zabawił na mieście i o tej porze nawet "przyjacielskiego i życzliwego domu nie wypadało odwiedzić" 53 . Ciekawą uwagą zamieszczoną w liście była ta o nowej metodzie, którą Kryciński wprowadził w szkole we Lwowie ${ }^{54}$, a którą Daczyński niezwykle

48 Korespondencja Waleriana Krycińskiego z lat 1874-1928, t. 1: A-H, 157.

49 Ibidem.

50 Ibidem.

51 Ibidem.

52 Krycińscy mieszkali na ul. Jabłonowskich 2, na II piętrze.

53 Korespondencja Waleriana Krycińskiego z lat 1874-1928, t. 1: A-H, 158.

54 Sam Kryciński o metodzie, którą opracował, wypowiedział się następująco: „Już w latach 1882 do 1889, gdy kierowałem Krajowa Szkołą Garncarską w Kołomyi, gdzie 
zachwalał. Wyraził przekonanie, że tylko dzięki tej metodzie „uzupełnimy naszą sztukę zdobniczą rodzimą" ${ }^{55}$. Co ciekawe, obaj artyści mieli widać takie samo podejście do rysunku, skoro już w drugim zdaniu napisał, że sam prowadzi uczniów od roku taką samą metodą, jednak brak mu środków oraz pomieszczenia, w którym mógłby dobrze uczyć,

uczyłem rysunków odręcznych i dekoracji naczyń, przestałem używać wzorów w różnych reprodukcjach, modeli drucianych, drewnianych, gipsowych, wprowadzając do nauki zdjęcia $\mathrm{z}$ malowań $\mathrm{z}$ miejscowych wyrobów garncarskich i projektowanie z tych motywów zdobień, i przekonałem się, że bez wzorów i różnego rodzaju modeli, umyślnie do nauki rysunków fabrykowanych obejść się można. W r. 1898, powołany do uczenia rysunków zdobniczych i malarstwa dekoracyjnego w Państwowej Szkole Przemysłowej we Lwowie, zacząłem samodzielnie, w ramach przepisanego planu naukowego, wprowadzać do nauki studium roślin i żywych zwierząt, szkicowanie poza salą rysunkową, jako też ćwiczenia pamięciowe i projektowanie zdobień na podstawie studjum analitycznego z natury lub motywów ludowych, ograniczając czem raz więcej kopjowanie wzorów i rysowanie z modeli gipsowych. Te same sposoby nauczania stosowałem w Liceum Żeńskim p. Niedziałkowskiej, jako też w Seminarjum Nauczycielskiem p. Zofii Strzałkowskiej we Lwowie. Także na rządowych kursach uzupełniających dla nauczycieli szkół wydziałowych i kursach technicznych dla nauczycieli szkół przemysłowych uzupełniających, na których prowadziłem naukę rysunków, stosowałem metodę nauczania obowiązującą już w państwowych szkołach przemysłowych, a opartą na studium żywej natury, bez kopjowania wzorów i rysowania modeli gipsowych. W roku 1912 i 1913 umieściłem w piśmie zawodowem, poświęconem sprawom wychowania artystycznego i nauki rysunków p.t. «Kształt i Barwa» wydawanym we Lwowie przez prof. St. Matzkiego, rocznik I - zesz. 1, 2 i 4, trzy artykuły p.t.: «O nowej metodzie nauczania rysunku zdobniczego w państwowych szkołach zawodowych, przemysłowych i artystyczno-przemysłowych», jako wyjątki z tworzącej się już niniejszej książki. Stosując te nowe metody nauczania, przekonałem się, że nie tylko sam dobór modeli ułatwi naukę i wpłynie na raźniejsze rozwijanie zmysłu spostrzegawczego i rozbudzenie większego zamiłowania u uczącej się młodzieży, ale trzeba także umiejętnie stosować technikę i środki wykonania danego przedmiotu jako modelu rysunkowego, szczególnie w tych kategoriach szkół, w których jest bardzo niewielka liczba godzin przeznaczona na naukę rysunków, jak np. w seminariach nauczycielskich lub szkołach średnich. Czyniąc w tym kierunku doświadczenia przekonałem się np., że uczniowie z klas niższych trafiają kształty płaskie, a nawet bryły, daleko lepiej, rysując od razu pendzlem w sylwecie, niż dawnym sposobem, znacząc najpierw te kształty cienką kreseczką ołówkiem w konturze. Zwierzęta żywe, nawet w ruchu, trafiają uczniowie pendzlem znacznie lepiej, jak rysując je najpierw w konturze. Tworzenie zdobień i projektowanie ornamentów postępuje znaczniej łatwiej, jeżeli używamy pendzla lub posługujemy się nożyczkami i papierami barwnemi, a nie zaczynając tego od rysowania ołówkiem. Odpowiednie użycie węgla do wykonania rysunków w dużym formacie, do powiększania, a szczególnie do znaczenia światłocienia, jest znacznie praktyczniejsze, jak używanie do tego celu ołówka, kredy lub sangwiny. Dobierając starannie modele i stosując odpowiednie techniki wykonania ćwiczeń z uczniami, stwierdziłem znacznie raźniejszy postęp w rozwoju zmysłu spostrzegawczego we wszystkich kategoriach szkół, w których uczyłem, [...]”, Walerian Kryciński, Rysunki odręczne, zdobnicze $i$ malarstwo dekoracyjne. Nowe metody nauczania w szkołach różnych typów, wedtug planów Ministerstwa W.R I O.P. (Lwów-Warszawa-Kraków: Wydawnictwo Ossolineum, 1926), XV-XVI.

55 Korespondencja Waleriana Krycińskiego z lat: 1928, t. 1: A-H, 158. 
a co najważniejsze ma słabych uczniów. Spuentował to słowami: „(wiesz jacy się zapisują), ale koniec końców mogą się po trzech latach nauki tyle nauczyć, że potrafią z natury naszkicować i skomponować samodzielnie projekt"56. Z pewnością musiał być pod dużym wrażeniem całokształtu dokonania Krycińskiego, skoro zaraz po tym zdaniu dopisał, że jest mu winien wyrazy uznania, gdyż zdaje sobie sprawę, ile pracy i sprytu musiał włożyć, żeby dobrać modele do rysunku. Zapowiedział też, że $\mathrm{z}$ pewnością przy najbliższej okazji porozmawiają „w tym materyale” ${ }^{57}$.

Następny z listów nosi datę 20 maja 1908 r. Rozpoczyna się bardzo serdecznie, bo i musiało wzbudzić radość w Daczyńskim otrzymanie od przyjaciela dwóch kart z jego podobizną. Tym bardziej, że podobizna była namalowana $z$ brawurą przez „znakomitego Jacka” ${ }^{58}$, i jak dodaje zaraz Daczyński: „przed którym zawsze staję z czapką w ręku” ${ }^{9}$.

Możemy niestety tylko przypuszczać, choć $\mathrm{z}$ dużą dozą prawdopodobieństwa, że owym Jackiem był sam Jacek Malczewski' ${ }^{60}$. Zważywszy na kategorię brawury, którą wymienia nasz autor w liście, można - znając styl Malczewskiego - śmiało tę tezę postawić. Niestety nie mamy wiadomości, co z rzeczonym obrazem się stało. Daczyński zauważył, że obraz zdecydowanie przysporzy Krycińskiemu znacznej popularności i reklamy, co jego zdaniem, jest bardzo potrzebne i ważne.

Tyle z przyjemnych informacji, które autor przesyła przyjacielowi do Lwowa. Następna z nich jest nieco dla niego przykra. Otóż w sali rysunku w szkole w Kołomyi zawaliły się szafy. I choć była to katastrofa, to jednak Daczyński uważał ją za wielką dobroczynność losu. W miejscu, gdzie te szafy stały, pokazał się na ścianie - graniczącej z toaletami - ogromny grzyb $^{61}$. I jak relacjonował:

56 Ibidem.

57 Ibidem.

58 Korespondencja Waleriana Krycińskiego z lat 1874-1928, t. 1: A-H, 160.

59 Ibidem.

60 Jacek Malczewski (1854-1929) - polski profesor, artysta malarz. Vide: Dorota Kudelska, Dukt pisma i pędzla. Biografia intelektualna Jacka Malczewskiego (Lublin: Wydawnictwo KUL, 2008).

61 Problem narażenia szkoły na skutki zawilgocenia znany był już w 1899 r. W Sprawozdaniu z czynności Komisji krajowej dla spraw przemysłowych za czas od 15 grudnia 1998 do 18 grudnia 1899 znajdujemy taki zapis: „Szkoła wymaga tedy rozszerzeń pod względem swego umieszczenia, dodatkowych maszyn pomocniczych i pieców, aby mogła w zupełności celowi swemu odpowiedzieć. Czy się to da uskutecznić w Kołomyi? Czy wypada dążyć do rozszerzenia budynku szkolnego narażonego z powodu swego położenia na wylewy i już dziś wilgocią mocno uszkodzonego?", Sprawozdanie z czynności Komisji krajowej dla spraw przemysłowych za czas od 15 grudnia 1898 do 18 grudnia 1899 (Lwów: Związkowa Drukarnia we Lwowie, 1899), 12. 
tak się rozrósł, że by można z niego futro dla kilku dam zrobić - kolosalne płachty nawet mur przeżarły. I pomyśl sobie Kochany, że ja go przez tyle lat co dzień pół dnia, a czasem cały dzień suszę swoimi kościami. Wpływa to szkodliwie na słuch i wzrok, bo i memu sąsiadowi słuch słabnie (Łuszczewskiemu), a słyszał - jak to mówią - jak trawa rośnie ${ }^{62}$.

Daczyński z pewnością miał rację, gdyż szkodliwość tego okazu z rodziny strzępkowych - przez wydzielane mykotoksyny - musiała nadwerężyć zdrowie artysty. W związku $\mathrm{z}$ tym w wakacje zaplanował wyjazd do Iwonicza, żeby poprawić stan swojego zdrowia.

Daczyński narzeka też, że nie maluje zbyt dużo, ponieważ - lokalnie - nie ma odbiorców, ale przede wszystkim nie ma bodźców, które by go inspirowały. Informuje Krycińskiego, że namalował swój portret, a jak jeszcze namaluje portret żony, to go wyśle w jesieni na wystawę, „żeby się przypomnieć, że jeszcze żyję" ${ }^{3}$. Po wymianie tej korespondencji w dostępnych archiwaliach znajdujemy znaczną przerwę. W żaden sposób nie możemy przypuszczać, jak zresztą i poprzednio, że nastąpiło jakieś dłuższe ochłodzenie kontaktów między oboma malarzami.

List z 29 grudnia 1913 r. odwołuje się do korespondencji, którą Daczyński otrzymał od Krycińskiego; zapewne były to życzenia świąteczne, na które niezwłocznie dał odpowiedź. Daczyński zaczyna od słów:

\section{Kochany Walery!}

Wzruszyła mię Twa kartka, jest to dowód pamięci o Twym dawnym towarzyszu - kiedy to jeszcze młodzi a „jurni” byliśmy. Wierzaj mi, że moje życie nie wesołe - nie o takim marzyłem. Wprawdzie minimum egzystencji - jakie przeciętny filister potrzebuje - mam - ale strawy dla umysłu i naszych aspiracji brak. Znasz tutejsze otoczenie i warunki, więc resztę sobie dośpiewasz. W szkole z malarza zostałem „kominiarzem” - bo taki obecnie kierunek. Dekoruje się bardzo mało - nie ma kim, bo co którego nauczę, to ucieka tam gdzie mu lepiej płacą ${ }^{64}$.

Daczyński wiedział, że nie miał już zbyt wiele czasu na rozwinięcie swojego kunsztu malarskiego. Jak dodał nieco dalej, musiał uczyć i siebie,

62 Korespondencja Waleriana Krycińskiego z lat 1874-1928, t. 1: A-H, 160.

63 Ibidem.

64 Ibidem, BJ, 162-163. 
i uczniów, jak planować i konstruować nowe piece, i było to zajęcie raczej techniczne niż artystyczne. Pociechą dla niego była obecność w Kołomyi innego malarza - Stanisława Gałka ${ }^{65}$, który pracował w Szkole Przemysłu Drzewnego w Kołomyi. Obaj artyści pochodzący z tych samych okolic spotykali się widać z przyjemnością. Daczyński przyglądał się też sztuce zdobienia, którą Gałka próbował uskuteczniać w jego pracowni. Robił to dla siebie i wprowadzał nowe formy „o motywach wyłącznie polskich. Niektóre bardzo ładne - a właściwie przez to, że naiwne [...]" ${ }^{66}$. Daczyński przyznawał się, że technika stosowana przez Gałkę była mu obca, a chcąc się jej nauczyć, musiałby poświęcić na to wiele czasu.

W dalszej relacji do Krycińskiego skarżył się, że bardzo mało maluje. Zdarzało się mu, że czasem namalował jakiś portret, ale „najczęściej pastelem na szarym Lenbachu"67. Smutku dokładał Daczyńskiemu stan żony, która bardzo miała bardzo słabe serce. Jak zaznacza, „już wiele razy obawiałem się nagłej katastrofy"68.

65 Stanisław Gałek (1876-1961) - polski malarz, rzeźbiarz i projektant. Studiował na ASP pod kierunkiem Jacka Malczewskiego i Jana Stanisławskiego. Dalsze studia odbył w Monachium i Paryżu. Pracował we Włoszech i Rosji. Od 1912 do 1916 r. nauczyciel w Szkole Przemysłu Drzewnego w Kołomyi. Od 1916 r. zamieszkał w Zakopanem i tam pracował. Vide: Rzecz o Morskim Oku, tatrzańskich stawach i górach we mgle w twórczości Stanisława Gałka, https://polskiemuzy.pl/rzecz-o-morskim-oku-tatrzanskich-stawach-i-gorach-we-mgle-w-tworczosci-stanislawa-galka- (dostęp: 16.11.2020).

66 Korespondencja Waleriana Krycińskiego z lat 1874-1928, t. 1: A-H, 160.

67 Ibidem.

68 Ibidem. 
Ryc. 8. S. Daczyński - Szkic do portretu sąsiadki - Kołomyja 1913 rok - rys. ołówkiem

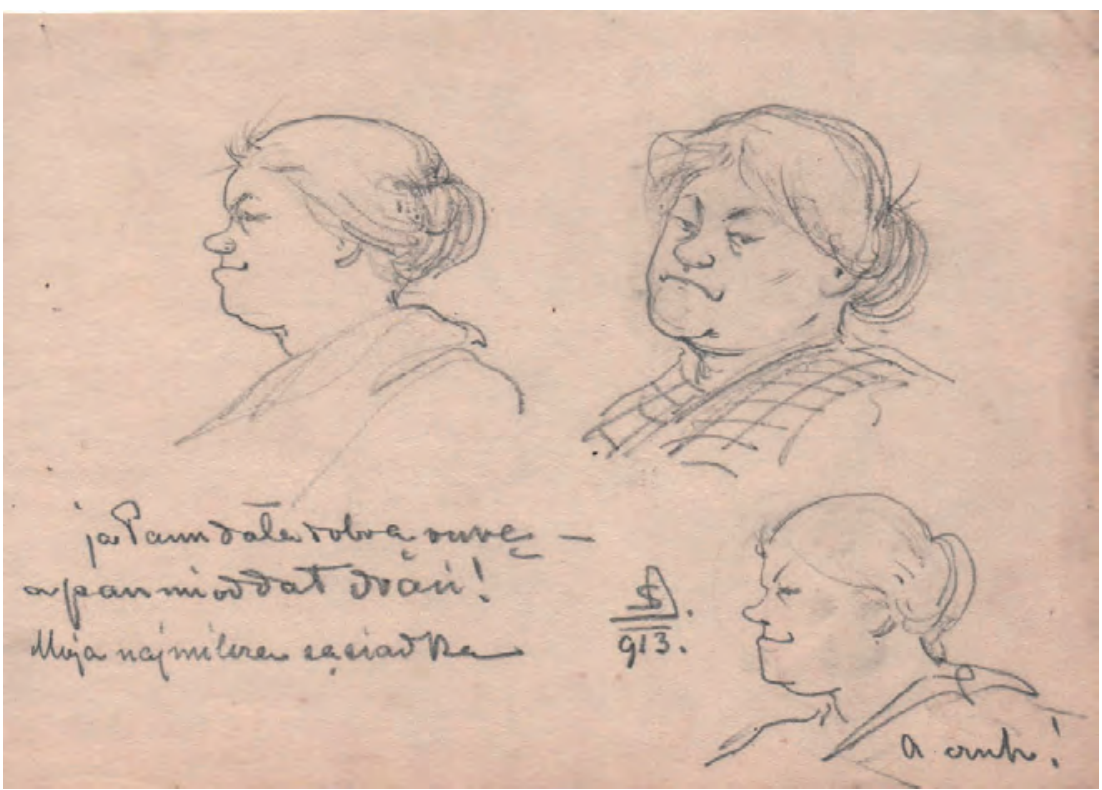

Źródło: zbiory autora.

Do katastrofy doszło, jednak była ogólnoświatowa. Wybuch wielkiej wojny w Europie pogmatwał także losy Daczyńskich. Dowiadujemy się o tym z listu z 24 kwietnia 1916 r. Nieszczęście rozpoczęło się najprawdopodobniej na początku października 1914 r, a być może nieco wcześniej. Nieobecność Daczyńskich w Kołomyi, ich ucieczkę przed rozpoczętą wojną - szacujemy na podstawie listu, w którym Daczyński pisze, że w samym Wiedniu mieszkali „stale przez 14 miesięcy” 69 - zaś wrócili do Kołomyi w grudniu $1915 \mathrm{r}^{70}$ Wróćmy jednak do samego początku, czyli ich wyjazdu z Pokucia.

Oddajmy głos samemu autorowi, który zrelacjonował swoje perypetie w następujących słowach:

My uciekliśmy końmi do Mikuliczyna, a stamtąd w pakwagonie do Satmar Nemet ${ }^{71}$ na Węgrzech. Podróż trwała 5 dni wśród śmiertelnej udręki.

69 Ibidem, 164.

70 Ibidem.

71 Właściwie: Szatmárnèmeti. Obecnie Satu Mare - miasto w Rumunii, wówczas w Królestwie Węgier w obrębie monarchii Habsburgów. 
W Szatmar zamieszkaliśmy w opuszczonej cegielni - w domku robotniczym - gdzie przez 4 tygodnie spaliśmy pokotem na podłodze na omłotach słomy. Robiłem tam rzeczy, o których nigdy mi się nie śniło, bo nawet bieliznę prałem w węgierskim korycie przy studni ${ }^{72}$.

Widać, że Daczyński nie przywykł do jakichkolwiek prac, a i z pewnością nie należał do ludzi, którzy przygotowani byli do życia w warunkach pozadomowych. Po tak nieprzyjemnym początku i kilku dniach spędzonych w małej miejscowości Daczyńscy trafiają do Wiednia. Ton wypowiedzi Daczyńskiego ulega zmianie, zdecydowanie stolica Austrii była miejscem, które go zauroczyło, o czym też doniósł Krycińskiemu.

W Wiedniu oraz w zwiedzanych przez miesiąc okolicach Daczyński odzyskał wenę. Wykonał wiele szkiców, które się zachowały, obserwował architekturę i korzystał z możliwości delektowania się sztuką stolicy monarchii. W liście do Krycińskiego przykuwa jednak uwagę co innego jego wrażliwość na to, że w Galicji wszystko jest niezwykle zapóźnione. Przysłowiowa bieda galicyjska była czymś realnym, a w zetknięciu się z tym, co zobaczył w Austrii, wydawała się czymś strasznym i deprecjonującym. Zrelacjonował to w sposób bardzo emocjonalny:

widząc jak nawet najskromniejszy wieśniak lub szewc mieszka, przychodziła mi refleksja: jak my biedni i opuszczeni w Galicji jesteśmy, jak nie mamy pojęcia o wygodzie, czystości - komforcie. Lud tam bardzo kulturalny i dobry i dla nas obcych bardzo uprzejmy w obcowaniu ${ }^{73}$.

Szczęście nie mogło trwać wiecznie, bo i pewnie fundusze, które posiadali, mogły być na ukończeniu.

Zatem - jak już wspomniano - Daczyńscy w grudniu 1915 r. powrócili do Kołomyi. Tutaj niestety spotkało ich duże rozczarowanie, ponieważ z pracowni Daczyńskiego zniknęly wszystkie przybory do pracy. Chcąc zarobić, nasz artysta nie miał czym. Pisał: „Mam zamówienia i jestem w położeniu szewca, który ma zrobić parę butów, a nie ma skóry i kopyt" 74 . Widać, że ta podróż bardzo zmieniła Daczyńskiego, gdyż już w drugim zdaniu napisał, że nie ma na co narzekać, gdyż znieśli te problemy dość dobrze, a sam pobyt w Wiedniu bardzo mu służył. Co więcej, stał się dla niego jakby powtórką ze studiów. Nie mówiąc już o tym, że żaden ze szkolnych inspektorów, których musiał słuchać na

72 Korespondencja Waleriana Krycińskiego z lat 1874-1928, t. 1: A-H, 165.

73 Ibidem.

74 Ibidem. 
konferencjach, nie dał mu tyle, ile odwiedziny w muzeach i szkołach wiedeńskich. Konkludował słowami: „pokochałem to miasto tak, że połowę serca zostawiłem tam wyjeżdżając" 75 .

Na tym liście zakończyła się - dostępna nam na tę chwilę - korespondencja Stanisława Daczyńskiego z Walerianem Krycińskim. Pozostają pytania: Czy miała ciąg dalszy? Czy istnieją jeszcze gdzieś inne listy? No i czy spotykali się jeszcze po skończonej wojnie? Być może ich losy przed śmiercią Krycińskiego znów się ze sobą związały w jakimś stopniu, choć już nie w Kołomyi, a w Krakowie, gdzie obydwaj - ostatecznie - zamieszkali. W żadnym wypadku nie można wykluczyć twierdzącej odpowiedzi.

Ryc. 9. S. Daczyński - Autoportret - Wiedeń 8 VII 1915 r. - rys. ołówkiem

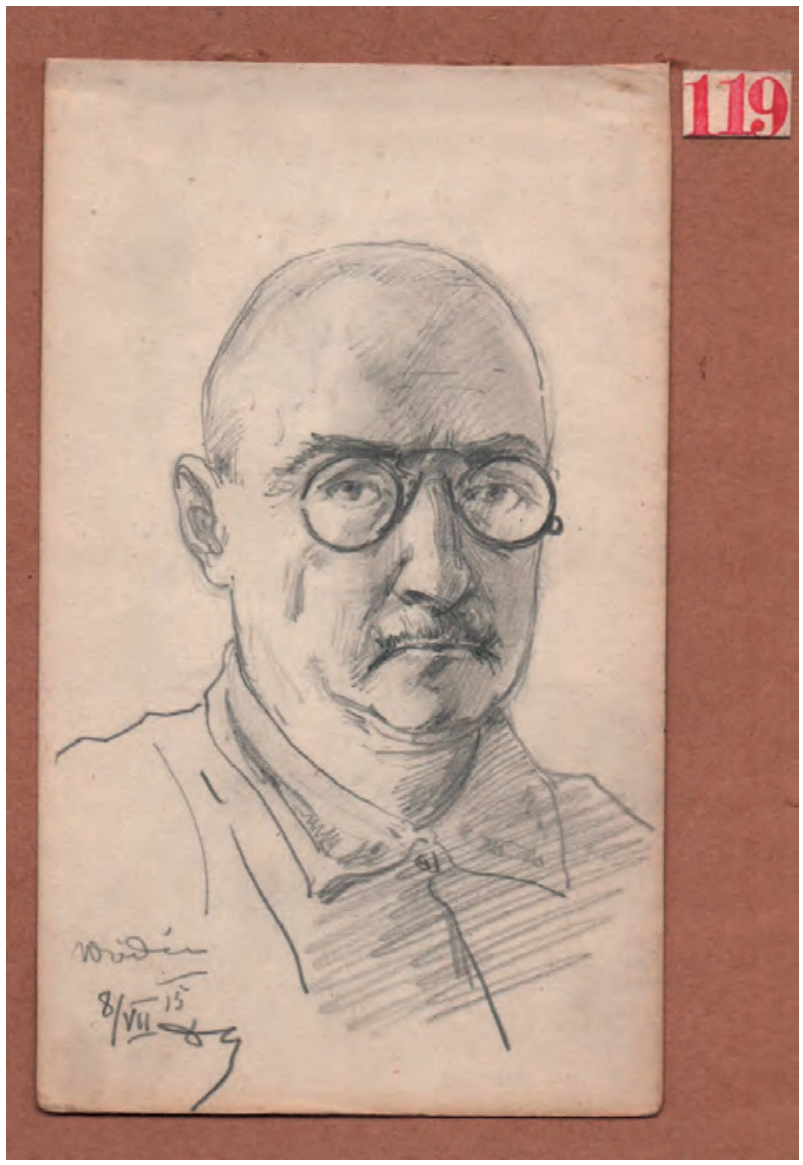

Źródło: zbiory autora. 
Ryc. 10. S. Daczyński - Portret dziewczyny - Wiedeń 18 VII 1915 r. - rys. ołówkiem

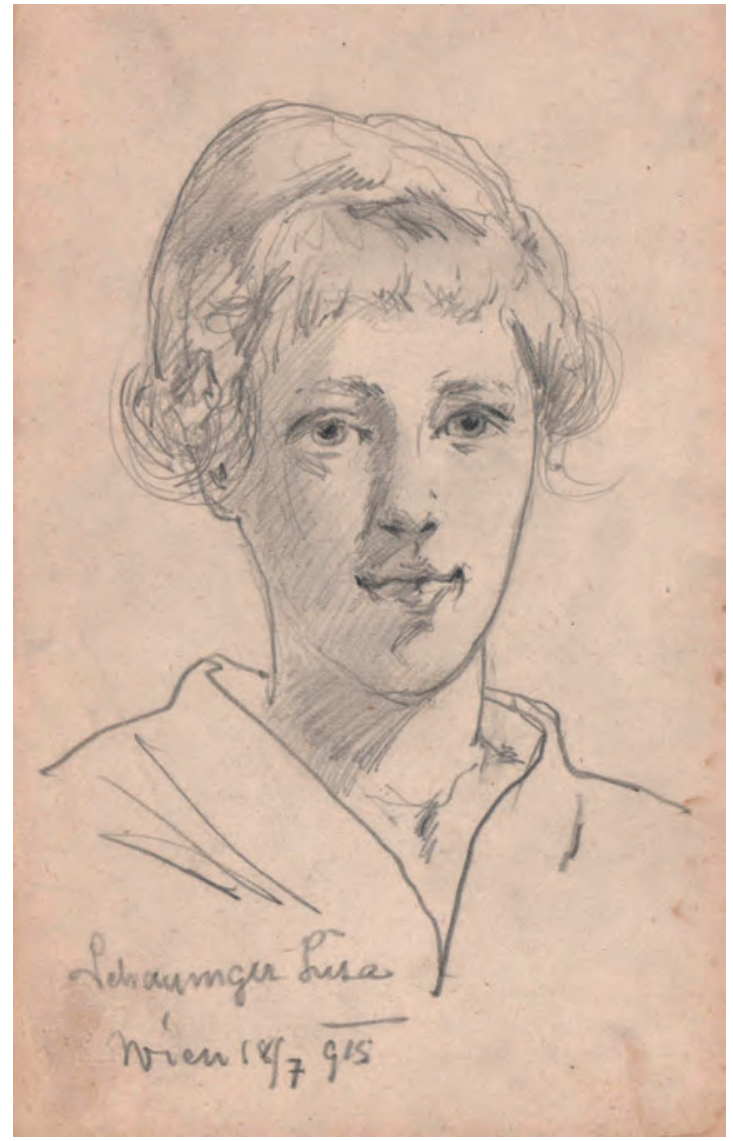

Źródło: zbiory autora.

\section{Dodatek do biografii}

Po analizie zawartości korespondencji Daczyńskiego z Krycińskim, która przybliżyła nam nieco jego pobyt w Kołomyi, pozwolimy sobie na uzupełnienie - niezbyt zresztą obfite - danych biograficznych Stanisława Daczyńskiego odkrytych na podstawie kwerend archiwalnych i własnego zbioru dokumentów. Rodzicami Stanisława byli Jan i Weronika z domu Bendykiewicz ${ }^{76}$, o których niestety posiadamy bardzo skąpe informacje.

76 Parafia św. Szczepana w Krakowie, Liber defunctorum, 162. 
Udało się jednak ustalić, że ojciec Stanisława - Jan Sylwester Daczyński zmarł 31 marca 1915 r. w Bochni w wieku 87 lat. Stanisław nie przyjechał na pogrzeb ojca. Był wówczas w Wiedniu i nie jest pewne, czy wiadomość dotarła do niego na czas, a jeśli nawet tak się stało, to jest bardzo mało prawdopodobne, by był w stanie dojechać do Bochni.

Światło na sprawy związane z pogrzebem Jana Daczyńskiego oraz $\mathrm{z}$ wszystkimi formalnościami z tym związanymi daje nam relacja Jana Piekarza, ówczesnego lustratora rady powiatowej w Bochni, a prywatnie krewnego Daczyńskich. W dniu 18 kwietnia 1915 r., czyli ponad dwa tygodnie po pogrzebie, wysłał do Stanisława wiadomość, która jest zapisana na odwrocie pisma wystosowanego przez niego do c.k. dyrekcji skarbu. Ze względu na ciekawy charakter kulturowy tego dokumentu pozwolimy sobie przytoczyć go w całości:

\section{Wysoka c.k. krajowa Dyrekcyo skarbu.}

Dnia 31 marca 1915 zmarł w Bochni w 87 roku życia wuj żony mojej śp. Jan Sylwester Daczyński, emerytowany c.k. starszy zarządca podatkowy. Metrykę śmierci dołączam. Ponieważ tak dzieci Jego, jak i żona moja rozproszone z powodu zawieruchy wojennej po świecie - jak w Kołomyi, Dolinie, Wiedniu i w Neutitschein - mimo najszczerszych chęci nie mogły zająć się tym staruszkiem ani przed śmiercią, ani też po śmierci, przeto ja jako powinowaty i stale w Bochni zamieszkały, zająłem się Nim - tak przed śmiercią, a w szczególności po śmierci w ten sposób, że jak dołączony rachunek firmy pogrzebowej Franciszka Małka wykazuje, sprawiłem śp. Zmarłemu - wedle stanu - przyzwoity pogrzeb za 583 kor. 30 hal., rozdałem według życzenia zmarłego 12 kor. biednym na cmentarzu w dniu pogrzebu, słudze zaś - Karolinie Hejmo, która pielęgnowała i obsługiwała Zmarłego do ostatnich chwil życia Jego, dałem dnia 9 kwietnia br., jak wykazuje dołączone pokwitowanie - kwotę 284 kor. 70 hal., tj. taką kwotę, jaka by się jej po opędzeniu kosztów pogrzebu z kwartału pośmiertnego słusznie należała. Wszystkie te wydatki pokryłem jednak z kwoty 900 koron, jaką po Zmarłym w Jego stoliku w obecności świadków znalazłem. Wobec tego upraszam c.k. krajową Dyrekcyę skarbu o wyasygnowanie przypadającego kwartału pośmiertnego na moje ręce, tak jak sobie tego życzą dzieci Zmarłego, a mianowicie Stanisław Daczyński i Janina Balicka z Kołomyi, obecnie w Wiedniu zamieszkali.

Stemple na podanie i 4 załączniki zechce c.k. krajowa Dyrekcya skarbu zarządzić ściągnąć z przypadającego kwartału pośmiertnego.

Bochnia, dnia 18 kwietnia 1915.

Jan Paweł Piekarz m.p.

Lustrator Rady powiatowej ${ }^{77}$.

77 APA, List Jana Piekarza do Stanisława Daczyńskiego, mps, rkps (Bochnia: 18.04.1915). 
Dyrekcja c.k. skarbu z Białej nie wydała zgody na wypłacenie Piekarzowi kwoty. Odmowa została wyrażona pismem urzędowym z dnia 27 kwietnia 1915 r. Urząd kierował się przepisem prawnym, który orzekł, że „kwartał pośmiertny należy się wdowie, a w braku tejże ślubnym potomkom zmarłego, którzy mają tu sami wnieść odnośną prośbę $\mathrm{z}$ wykazaniem prawa do kwartału pośmiertnego"78. Tę informację Piekarz przekazał przebywającemu wówczas w Wiedniu Daczyńskiemu w liście z dnia 4 maja 1915 r. Piekarz przesłał Daczyńskiemu także testament ojca oraz poinformowal go co do sposobu dysponowania środkami z książeczki oszczędnościowej. Ciekawostką jest jednak decyzja Daczyńskiego, którą wykonał, a dotyczyła ona zadysponowania rzeczami osobistymi, które zostały po zmarłym Janie. Treść tej decyzji jest następująca:

Stosownie do życzenia Twojego, wyrażonego w ostatniej kartce, przechowałem starannie rzeczy pamiątkowe po św. Ojcu jak: stary istotnie wartościowy zegar, zegarek, szpadę, strzelbę, dwa obrazy a także pełną paczkę jakichś książek i papierów. Wannę - pochodzącą od mojej żony, życzy sobie żona zatrzymać. Przywieźliśmy tę wannę dla śp. Wuja ze Lwowa. Futro krótkie, dobre na objazdy komisyjne pod bundę, zatrzymam dla siebie na pamiątkę po miłym śp. Starcu. Wszystkie zresztą sprzęty: pościel, bieliznę, serwis, garderobę, etc., drobiazgi pozostawiłem Karolinie, stosownie do Twojego postanowienia, co i ja zupełnie słusznie uznaję. W tych dniach wyjeżdżam do Nutitschein może na 3 dni, aby zawieść żonie i córkom wiosenne rzeczy ${ }^{79}$.

Z treści listu wynika, że Daczyński był bardzo wrażliwy na zadośćuczynienie osobie opiekującej się jego ojcem, czyli służącej - Karolinie Hejmo $^{80}$ - której przekazuje rzeczy użytku codziennego ojca. Wygląda na to, że mieszkanie w Bochni zostało opróżnione. Nie wiadomo jednak, czy mieszkanie było własnością Daczyńskiego, czy też było wynajmowane od kogoś. Niemniej jednak 28 października 1916 r. c.k. Wydział Krajowy w Białej wysłał do c.k Urzędu Podatkowego w Bochni pismo dotyczące poborów Daczyńskiego za pracę w szkole ceramicznej w Kołomyi, z poleceniem wypłacenia mu należnych środków. Odpis decyzji trafił także do rąk Daczyńskiego. Co ciekawe, list zaadresowany był na adres w Bochni na ul. Gołębią $1200^{81}$.

78 APA, List C.K. Galicyjskiej Dyrekcji Skarbu L.17210/15 do Pana Jana Pawła Piekarza lustratora Rady powiatowej, mps, rkps (Biała: 27.04.1915).

79 Ibidem.

80 N.N.

81 APA, List do Stanisława Daczyńskiego - odpis listu c.k. Wydziału Krajowego w Białej do c.k. Urzędu podatkowego w Bochni, mps, rkps (28.10.1916). 
Zważywszy na to, że jeszcze w kwietniu Daczyńscy przebywali w Kołomyi, musieli zapewne w okresie wakacyjnym wyjechać do Bochni. Wątpliwe, by była to decyzja osobista. Raczej musiała mieć charakter administracyjny wynikający - być może - z trwania działań wojennych i konieczności zamknięcia szkoły. Nie było to zresztą niczym nadzwyczajnym, gdyż szkoły zajmowane były wówczas przez wojska obu frontów i traktowane jako szpitale lub koszary. Daczyńskiemu z pewnością było to na rękę, gdyż po przeprowadzeniu się do Bochni mógł uporządkować zaległe sprawy spadkowe. Nie wiadomo jednak, czy zamieszkał w mieszkaniu po ojcu, czy też u - wspomnianego już - krewnego Jana Piekarza.

Zdaje się, że pobyt w Bochni był dla Daczyńskiego dobry i kreatywny. Z tego okresu znajdujemy w szkicowniku kilka rysunków, które utrzymane są w bardzo miłym, a wręcz humorystycznym nastroju. Na rysunkach pojawiają się także coraz częściej sygnatury „SD”, wykonywane w różnym konwenansie, czasem połączone ze sobą lub luźne. Daczyński podpisuje nimi część rysunków, a co więcej uznane są one w literaturze przedmiotu za jego ex libris $^{82}$.

Ryc. 11. List C.K. Wydziału Krajowego w Białej do Stanisława Daczyńskiego Biała 1916

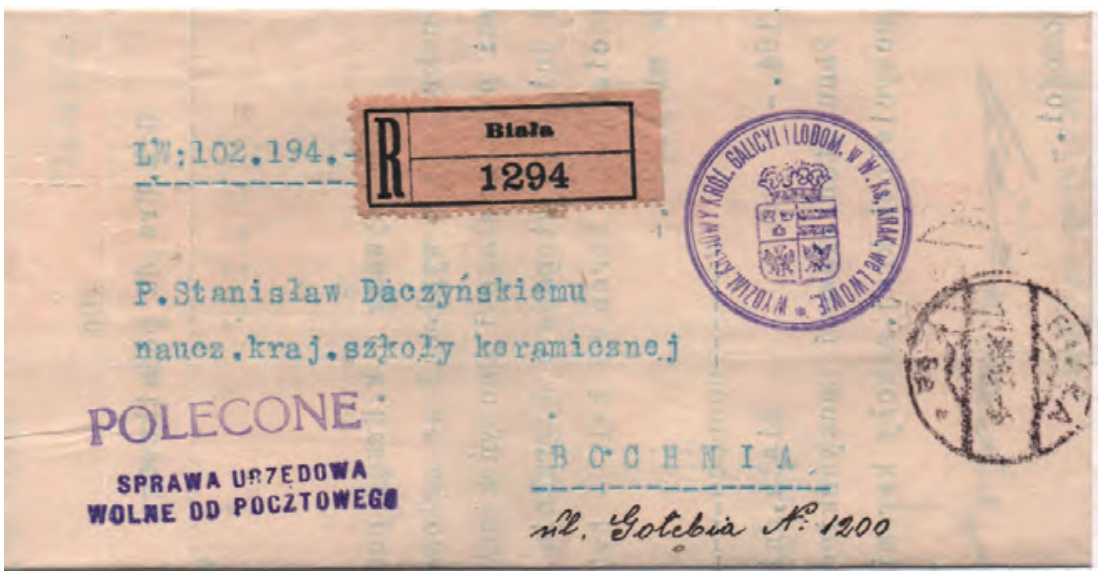

Źródło: zbiory autora.

82 Tomasz Surma, Sygnatury polskich twórców ekslibrisów od XIX wieku do współczesności. Leksykon (Warszawa: self-publishing, 2013), 64. 
\begin{tabular}{l|c} 
Od Kołomyi do Krakowa. Przyczynek do biografii Stanisława Daczyńskiego (1856-1941) & $\begin{array}{c}349\end{array}$
\end{tabular}

Ryc. 12. S. Daczyński - Sprzedaż jarzyn w Bochni - Bochnia 26 VII 1917 r. rys. ołówkiem

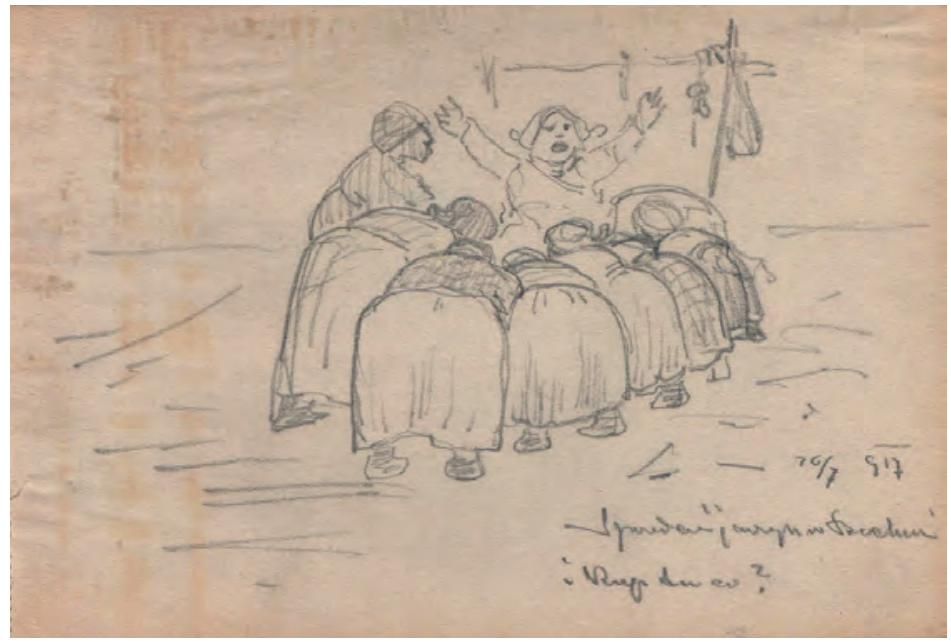

Źródło: zbiory autora.

Ryc. 13. S. Daczyński - Stefania Daczyńska - 20 IV 1917 r. - rys. ołówkiem

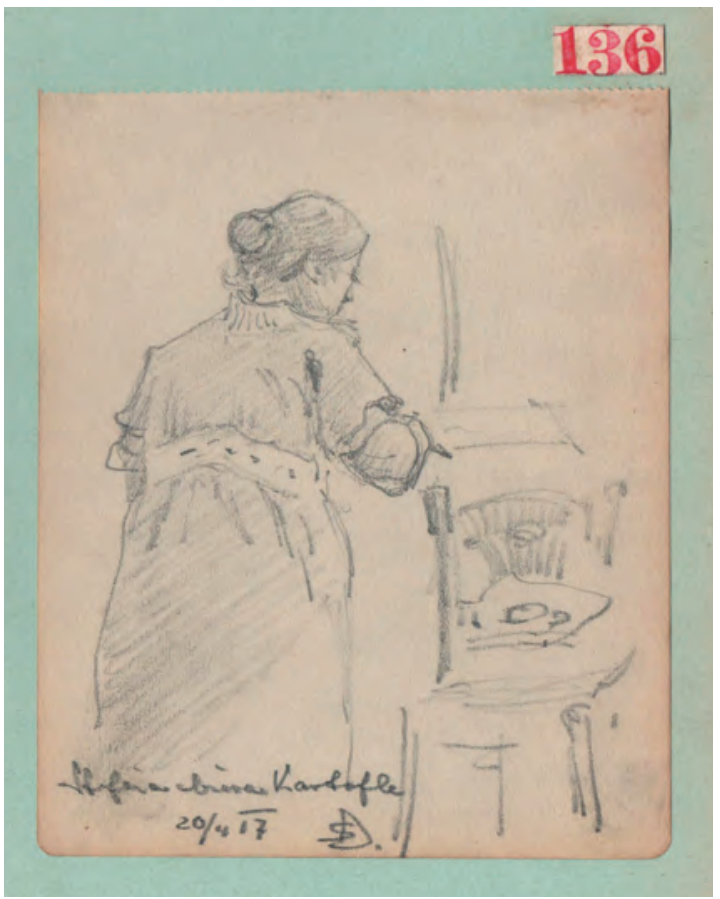

Źródło: zbiory autora. 
Stanisław Daczyński w Bochni pozostał - z dużą dozą prawdopodobieństwa - do końca lutego 1918 r. Do tego czasu wszystkie dokumenty urzędowe przychodziły właśnie na jego adres w Bochni. Najważniejszy z nich to list z dnia 7 stycznia 1918 r., który dotarł do niego ze Lwowa, z c.k. Wydziału Krajowego. Daczyński został w nim poinformowany, że do sześciu tygodni - w ramach obowiązków służbowych - zostanie przeniesiony do Lwowa i ma tam pracować w Krajowej Stacji Ceramicznej. W zakres jego obowiązków miało wchodzić:

1. Sporządzanie wzorów rysunków dla wyrobów garncarskich i kaflarskich, w zakresie uszlachetnionych form i ich dekoracji z uwzględnieniem szczególnem dekoracyi tzw. Bachmińskiego i dekoracyi za pomocą rożka.

2. Sporządzanie technicznych rysunków konstrukcyi pieców kaflowych, pieco-kominków, kominków i kuchen kaflowych z uwzględnieniem różnej ich wielkości i różnej wewnętrznej konstrukcji.

Tytułem wynagrodzenia za zniszczone podczas transportu koleją meble, zostanie Panu wypłacona 2 miesięczna płaca, tj. kwota $666 \mathrm{~K}$.

Pobory Pana we Lwowie wynosić będą:

a) Płaca $-3600 \mathrm{~K}$.

b) Dodatek pięcioletni - $400 \mathrm{~K}$.

c) Dodatku aktywalnego - $966 \mathrm{~K}$.

d) Woj. dod. Droż. Od 1/1/ 1918 do 30/6/1918 po 206 K.

e) Czyli kwotę 1236 K. w 6 ratach.

Do służby ma się Pan zgłosić w ciągu sześciu tygodni, licząc od dnia doręczenia niniejszego reskryptu ${ }^{83}$.

I tutaj stykamy się z pewną ciekawostką. Mianowicie Daczyński najprawdopodobniej nie podjął pracy we Lwowie, natomiast zwrócił się z prośbą o urlop, który - jak wynika z następnego pisma c.k. Wydziału Krajowego - dostał 9 kwietnia 1918 r. Daczyński wystosował ponowną prośbę o urlop do c.k. Wydziału we Lwowie. Wydział - w piśmie z 23 kwietnia 1918 r. - przychylił się do jego prośby i udzielił mu trzymiesięcznego urlopu. Nie był to jednak urlop w dzisiejszym tego słowa znaczeniu, raczej - gdyby pokusić się o porównanie - był to urlop naukowy. W czasie jego trwania Daczyński miał: „wykonywać projekta keramiczne, naczyń, pieców itp. I nadsyłać je stopniowo Kraj. Stacji

83 APA, List c.k. Wydziału Krajowego we Lwowie do Stanisława Daczyńskiego Lw. 46.449, rkps (Lwów: 07.01.1916). 
Keramicznej we Lwowie, nadto poleca się Panu być pomocnym przy uporządkowaniu i zabezpieczeniu inwentarza Kraj. Szkoły Kaflarsko-garncarskiej w Kołomyi" ${ }^{84}$. Daczyński trafił zatem z powrotem do Kołomyi. Tam przecież był jego dom, a co więcej mieszkała tam też - jak wiadomo z poprzednich doniesień - jego siostra.

Daczyński pozostał w Kołomyi nieco dłużej niż do czasu przejścia na emeryturę, które nastąpiło 31 marca $1920 \mathrm{r}^{85}$ Po uporządkowaniu inwentarza szkolnego szkoły garncarskiej w Kołomyi, mieszczącej się wówczas przy ul. Tarnowskich 763, wydział krajowy zwrócił się do Daczyńskiego z prośbą, by nadal opiekował się „inwentarzem szkoły, aż do chwili definitywnego oddania tegoż w przechowanie tamtejszego Magistratu"\$6. Daczyńskiemu przyznano za tę pracę dodatkową kwotę w wysokości 2536 koron $^{87}$. Najprawdopodobniej w Kołomyi Daczyński przebywał do lipca 1920 r., na co wskazywać by mogły dwa dokumenty z Wydziału Krajowego ze Lwowa. Pierwszy z nich skierowany był do Urzędu Podatkowego w Kołomyi, który nakazywał tamtemu urzędowi wypłacić „,jednorazowo tytułem zasiłku drożyźnianego za II kwartał 1920, Panu Stanisławowi Daczyńskiemu kwotę 88 marek 20 fenigów"88. Drugi zaś dokument to pismo Tymczasowego Wydziału Samorządowego ze Lwowa - z dnia 4 sierpnia 1920 r. - nakazujące urzędowi podatkowemu w Nowym Targu wypłacać przysługującą mu emeryturę. Miał ją otrzymać wraz ze zwyczajnym i nadzwyczajnym dodatkiem drożyźnianym w kwocie „cztery tysiące siedemset trzydzieści trzy marki 12 fenigów w ratach miesięcznych z góry" ${ }^{39}$. W piśmie wydział odnosił się do podania, które wniósł Daczyński 20 lipca tego roku. Adres Daczyńskiego podany na korespondencji ze Lwowa to: Zakopane, Krupówki rynek 906. Właścicielem mieszkania albo budynku był niejaki pan Lachowicz ${ }^{90}$.

Zapewne też Daczyński musiał jakiś czas poświęcić na uporządkowanie swoich spraw w Kołomyi, zanim przeniósł się do Zakopanego.

84 APA, List c.k. Wydziału Krajowego we Lwowie do Stanisława Daczyńskiego Lw. 34.082, rkps (Lwów: 27.03.1918).

85 APA, List Wydziału Krajowego we Lwowie do Stanisława Daczyńskiego, Lw. 48.825, rkps (Lwów: 03.03.1920).

86 APA, List Wydziału Krajowego we Lwowie do Stanisława Daczyńskiego, Lw. 16.177, rkps (Lwów: 07.05.1920).

87 Ibidem.

88 APA, List Wydziału Krajowego we Lwowie do Stanisława Daczyńskiego, Lw. 48.825, mps, rkps (Lwów: 10.05.1920).

89 APA, List Wydziału Krajowego we Lwowie do Stanisława Daczyńskiego, Lw. 29.836, mps, rkps (Lwów: 04.08.1920).

90 N.N. 
Trzeba wspomnieć, że był aktywny w zakresie projektowania lokalnego monumentu - „Pomnika Ofiar Kosaczowa” - mającego na celu uczczenie Polaków zmarłych w obozie stworzonym przez władze Zachodnioukraińskiej Republiki Ludowej w Kosaczowie ${ }^{91}$.

Pomimo przejścia na emeryturę Daczyński nadal chciał być aktywny. Starał się nawet o podjęcie pracy w charakterze nauczyciela, co wiemy z odpowiedzi Ministerstwa Wyznań Religijnych i Oświecenia Publicznego, które - listem z dnia 1 lutego 1921 r. - oświadcza, że „na terenie Małopolski i b. Królestwa Kongresowego nie rozporządza żadnem odpowiedniem dla Pana stanowiskiem" ${ }^{2}$. Ostatni dokument urzędowy z lwowskiego wydziału, potwierdzający pobyt Daczyńskiego w Zakopanem, pochodzi z 27 października 1922 r. ${ }^{93}$ Dotyczy on wniesienia wniosku o dodatek do emerytury za ukończone studia wyższe. Daczyński odręcznie dopisał na dokumencie, że wniósł o ten dodatek 3 listopada 1922 r. Adres, na jaki trafiała lwowska korespondencja, to: Zakopane - droga do Białego - dom Birtusa ${ }^{94}$.

Można się zastanowić, dlaczego Daczyński wybrał Zakopane zamiast innego miasta. Być może ze względów zdrowotnych. Było to jedno z uzdrowisk, które chętnie wybierali ludzie chcący podratować swoje siły witalne. Nie można wykluczyć, że zrobił to ze względu na żonę, o której chorobie wspominał w korespondencji do Krycińskiego. Stefania Daczyńska - mając 52 lata - zmarła 25 marca 1923 r. o godz. 6.30

91 Tak opisuje go przywoływany już Ryszard Brykowski: „Wzniesiony na cmentarzu rzymskokatolickim w części wojskowej dla uczczenia ok. 1000 (lub 1400) ofiar obozu internowanych Polaków na Kosaczowie, zorganizowanego przez władze Zachodnioukraińskiej Republiki Ludowej w latach 1918-1919. Wykonany według projektu artysty malarza Stanisława Leopolda Maksymiliana Daczyńskiego. Uroczyście poświęcony 10 września 1922 r. Po 1946 r. zniszczono marmurowe płyty z nazwiskami zmarłych, zamalowany m.in. napisami o treści wulgarnej i obraźliwej. Odnowiony w 1995 r. przez zespół pod kierunkiem Janusza Smazy, kierownika katedry konserwacji kamienia Akademii Sztuk Pięknych w Warszawie, z dotacji Rady Ochrony Pamięci Walk i Męczeństwa. [...]. Niegdyś część środkową wypełniały białe marmurowe płyty z nazwiskami zmarłych. [...] Obecny stan zachowania: pomnik ponownie zamalowany, pokryty napisami, łańcuch z krzyża zerwany i zabrany przez nieznanych sprawców, wymaga ponownie odnowienia, w przyszłości rekonstrukcji płyt z nazwiskami zmarłych”, Brykowski, Kołomyja: jej dzieje, zabytki, 85-86. Szkic pomnika został edytowany w poprzednim artykule poświęconym Daczyńskiemu. Duda, „Pokuckie i huculskie inspiracje", 29.

92 APA, List Ministerstwa Wyznań Religijnych i Oświecenia Publicznego do Stanisława Daczyńskiego, mps (Warszawa: 01.02.1921).

93 APA, List Wydziału Krajowego we Lwowie do Stanisława Daczyńskiego, Lw. 29.245, mps, rkps (Lwów: 27.10.1920).

94 Był to dom Stanisława Birtusa (1868-1943), kupca i działacza społecznego. Willa nosi nazwę „Boryna”. 
w Krakowie, w szpitalu na Garncarskiej, i spoczywa na Cmentarzu Rakowickim ${ }^{95}$. Ostatnie lata jej życia musiały być bardzo ciężkie. Jak dowiadujemy się z dokumentów archiwalnych, chorowała na raka piersi. I jak zanotował doktor Gólski ${ }^{96}$, ta właśnie choroba była też przyczyną zgonu ${ }^{97}$. W dopisku zaznaczono, że od 32 lat była żoną profesora z Zakopanego, a miejscem zamieszkania było także Zakopane ${ }^{98}$.

Być może spotkał się tam też ze Stanisławem Gałką, z którym łączyły go przyjazne stosunki w Kołomyi, a który w Zakopanem pracował. Zważywszy na artystyczny klimat tego miasta, Daczyński może i czuł, że tam odnajdzie przyjazne środowisko do tworzenia. W każdym razie w Zakopanem nie tracił czasu, gdyż wiadomo, że jego dzieła były wystawiane przez Towarzystwo „Sztuka Podhalańska”99. Prasa lokalna - w 1924 r. zachwalała jego „sceny myśliwskie” oraz „kompozycje”, stawiając je w jednym rzędzie z Wałachem ${ }^{100}$, Kotarbińskim ${ }^{101}$ i Malczewskim ${ }^{102}$.

95 Cmentarz Rakowicki: kwatera: X, rząd: pd., miejsce: 8.

96 N.N.

97 Archiwum Narodowe w Krakowie, Księga zmarlych chrześcijan 1923, t. 1 (Kraków: 1923), 150-151.

98 Ibidem.

99 Towarzystwo powstało 25 marca 1909 r. i działało do roku 1929. Pierwszym prezesem był Jan Gwalbert Pawlikowski, a pierwszym honorowym członkiem Stanisław Witkiewicz. Towarzystwo - jak pisał Jacek Woźniakowski - miało stymulować i zapewnić: „rozwój sztuki podhalańskiej i wprowadzenie jej do przemysłu artystycznego, opiekę nad zabytkami Podhala i utrzymanie jego stylowości. Środki do tego prowadzące: a) rozpowszechnianie zadań Towarzystwa słowem i drukiem, b) urządzenie wystaw, c) organizowanie pracowni i studiów artystycznych, d) ułatwianie zbytu wyrobów artystycznych, e) utrzymywanie biblioteki i własnych zbiorów", Jacek Woźniakowski, „O wystawach «Sztuki Podhalańskiej»”, Roczniki Humanistyczne 26/2 (1986): 525-526.

100 Jan Wałach (1884-1979) - polski malarz, rzeźbiarz i drzeworytnik. Michał Kawulok, „Artystyczna droga Jana Wałacha do niepodległej Polski”, Echo Wisły 237 (2018): 9.

101 Trudno powiedzieć, czy chodziło o Wilhelma Kotarbińskiego (1848-1921), czy też o Miłosza Kotarbińskiego (1854-1944).

102 Czesław Skawiński, „Towarzystwo „Sztuka Podhalańska« w Zakopanem”, Giewont. Ilustrowany kwartalnik zakopiański poświęcony sztuce, literaturze i sprawom rozwoju Zakopanego 1 (1924): 19-20. 
Ryc. 14. Dom Birtusa w Zakopanem - 1923 r.

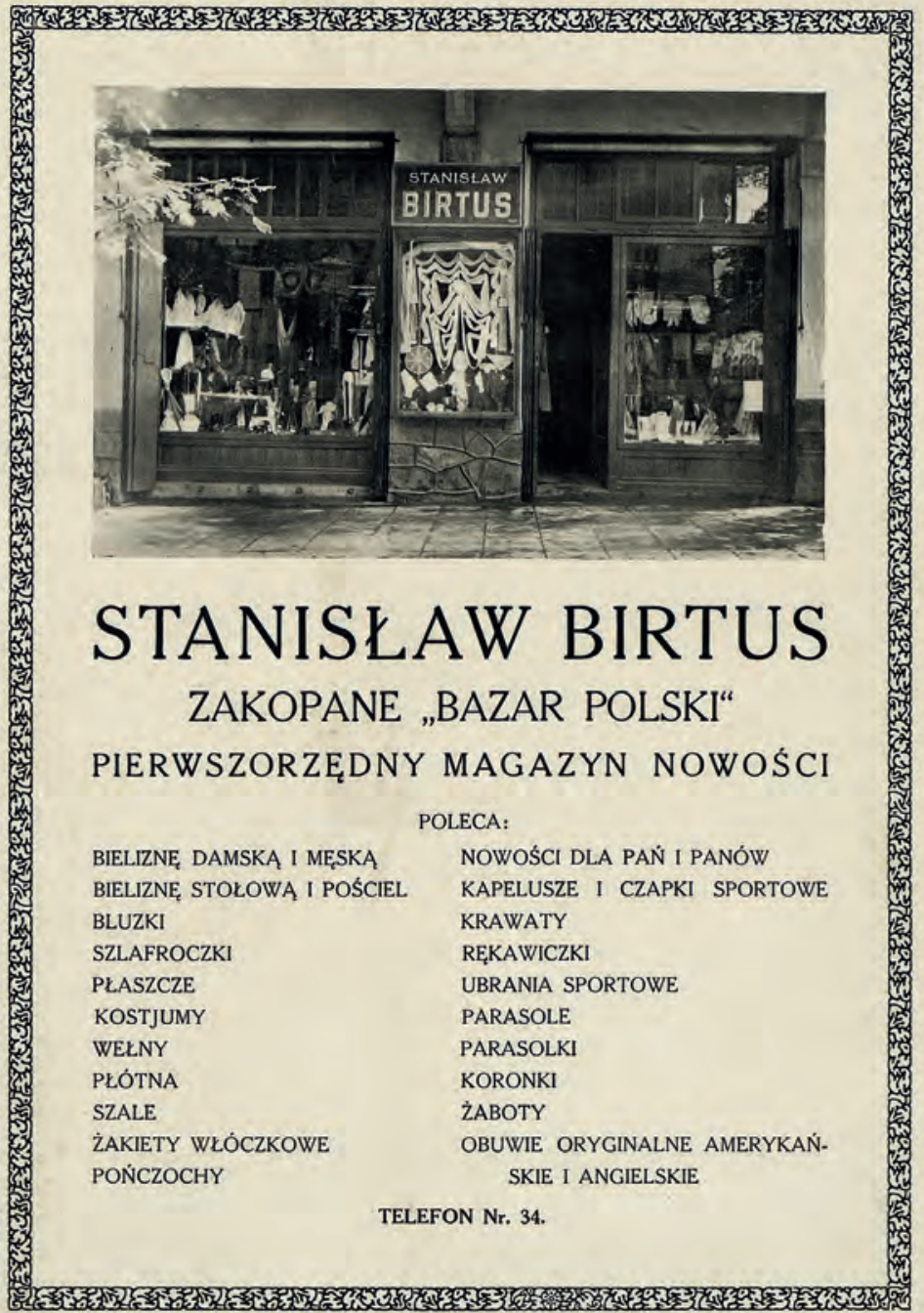

Źródło: Giewont. Ilustrowany kwartalnik zakopiański poświęcony sztuce, literaturze i sprawom rozwoju Zakopanego 1 (1924), 2.

Lata pomiędzy 1923 r. a śmiercią Daczyńskiego są jeszcze bardziej tajemnicze. Niestety poza skromnymi informacjami, mówiącymi zaledwie o tym, na których ulicach w Krakowie mieszkał, nie znajdujemy żadnych dodatkowych wskazówek. Można przypuszczać, że po śmierci 
żony żył z dnia na dzień, nie angażując się w poważniejsze przedsięwzięcia. Choć jednak trudno w to uwierzyć, bo trwało to jeszcze prawie dwadzieścia lat.

Jeśli zaś chodzi o datę śmierci Daczyńskiego, to - jak już wspominano $\mathrm{w}$ poprzednim artykule poświęconym malarzowi, była ona - $\mathrm{z}$ różnych przyczyn - podawana bardzo rozbieżnie. Nie można się też temu dziwić, gdyż zazwyczaj określano ją na podstawie ostatnich znanych dzieł artysty, zakładając, że swoje życie zakończył w podobnym okresie.

Daczyński umiera jako wdowiec - w wieku 85 lat - 11 sierpnia $1941 \mathrm{r}$. o godzinie $6.00 \mathrm{w}$ swoim mieszkaniu w Krakowie na placu Biskupim 4. Doktor Gólski ${ }^{103} \mathrm{w}$ akt zgonu wpisuje marasmus senitis - starczy zanik sił $^{104}$. Pogrzeb Stanisława Daczyńskiego odbył się 13 sierpnia $1941 \mathrm{r}$. Trudno wskazać jednoznacznie, gdzie został pochowany. Możemy jednak z dużą dozą prawdopodobieństwa wysnuć przypuszczenie, że także w Krakowie na Cmentarzu Rakowickim, gdzie wcześniej znalazła swoje miejsce spoczynku jego żona Stefania z Zajączkowskich Daczyńska.

Nie jesteśmy w stanie - na tę chwilę - stwierdzić tego faktu z zadowalającą pewnością, gdyż poza miejscem pochówku Stefanii nie ma danych o tym, by w tym samym grobowcu znajdował się także Stanisław. Możemy jedynie założyć, że w związku z tym, że był samotny, trwała wojna, jego pochówek miał charakter bardzo skromy i nikt nie zadbał o to, by utrwalić na nagrobku czy grobie jego danych. Nie był to pierwszy taki przypadek, a pewnie i nie ostatni.

\section{Zakończenie}

Próbując dokonać wstępnej syntezy życia i działalności Stanisława Daczyńskiego, do której przesłanki udało się zebrać na podstawie poprzednich i obecnych materiałów, możemy postawić tezę, że Daczyński jako malarz z pewnością nie czuł się spełniony. To jasno wybrzmiewa z jego listów. Niestety rzeczywistość, w której przyszło mu egzystować, nie dawała zbyt wielkiej szansy na sławę, zwłaszcza tym ludziom, którzy musieli sami walczyć o byt dnia codziennego. Nie wiemy, jakie przesłanki kierowały nim, by rozpoczął studia malarskie. Trudno też powiedzieć, jakie miał relacje z rodziną. Można przypuszczać, że nie było to przyjęte

\section{N.N.}

104 Robert Jahoda, Ksiegga Zmartych Chrześcijan 1941, rkps, (Kraków: 1941), n. 2542. Data i miejsce zgonu potwierdzone są także w księdze zgonów parafii św. Szczepana w Krakowie pod numerem 223, vide: Liber defunctorum, 162. 
z wielką aprobatą przez ojca - urzędnika austriackiego. O chłodnych relacjach mógłby przemawiać argument związany ze ślubem Daczyńskiego, kiedy to błogosławieństwa udziela Kryciński, nie zaś - żyjący jeszcze - ojciec Jan. Relacje małżeńskie, choć poprawne i zapewne zgodne z kanonem małżeństwa $\mathrm{z}$ tej epoki, nie dają nam obrazu sielanki, gdyż w dwóch listach wspominał, że gdyby był kawalerem, to zupełnie inaczej pokierowałby swoim życiem. Daczyńscy byli bezdzietni, co z jednej strony dawało im pewną wolność finansową, zaś z drugiej mogli być w jakiś sposób traktowani jako inni w towarzystwie. Oczywiście są to przypuszczenia, gdyż nie mamy żadnych twardych dowodów na takie postawy.

Daczyńskiego nie można jednak nie doceniać, gdyż z pewnością ma wkład w kulturę materialną tego okresu. Poza pracą malarską, nie bez znaczenia jest jego zaangażowanie w zdobnictwo ścienne znanych budynków, ale także sama praca z młodzieżą w Kołomyi. To stamtąd rozżarzony kaganek oświaty wrócił do źródła ceramiki pokuckiej, czyli do Kosowa i okolic, by wydać mistrzów ceramiki pokuckiej. Oczywiście można dyskutować, czy była to ceramika oryginalna, autochtoniczna, czy też zepsuta przez nowe wzory, które często daleko odbiegały od oryginalnej ceramiki huculskiej. Niemniej jednak każdy jej okaz - z tego okresu - wśród znawców kultury, muzealników czy kolekcjonerów jest niezwykle cennym nabytkiem.

Wiemy, że Daczyński - poza działalnością malarską - od młodych lat starał się też uczestniczyć w życiu społecznym. Jedną z ciekawostek jest to, że przesłał odpowiedź na słynną ankietę Józefa Rostafińskiego dotyczącą wykorzystania roślin w kulturze ludowej. W odpowiedzi listownej z dnia 4 września 1883 r. wysłał informację, że w okolicach Czarnego Dunajca górale nazywają ziemniaki "grulami” ${ }^{105}$. Wprawdzie nie była to wiadomość sensacyjna, ale pokazywała jego wrażliwość na potrzeby badań naukowych.

Dużą zagadką jest też - wspomniany przez Swieykowskiego - pamiętnik Daczyńskiego, w którym zapisywał z pewnością niezwykle ciekawe historie z życia. Odnalezienie takiego dokumentu jako żywej relacji tamtych wydarzeń dałoby możliwość rekonstrukcji oblicza dnia codziennego samego artysty, ale także relacji, które zachodziły między ludźmi różnych warstw społecznych. Zważywszy na jego kwiecisty, a i pełen humoru język, który można było zobaczyć zwłaszcza w korespondencji z Böhmem, świat przez niego przedstawiony byłby żywy, a być może i kolorowy barwami ludzkich charakterów. 
Pozostaje mieć nadzieję, że archiwa w Polsce i za granicą kryją sporo ciekawych informacji, które pozwolą na uzupełnienie pozostałych białych plam w biografii Stanisława Daczyńskiego. Nie można też wykluczyć, że ponowi się historia - podobna do tej z teką rysunków - i na rynku aukcyjnym lub w którymś $\mathrm{z}$ antykwariatów wystawiony zostanie znów jakiś obraz odnaleziony w - często - nieoczekiwanym miejscu.

\section{Bibliografia}

\section{Źródła archiwalne}

Jahoda Robert, Księga Zmartych Chrześcijan 1941, rkps (Kraków: 1941).

Korespondencja Waleriana Krycińskiego z lat 1874-1928. T. 1, A-H, Biblioteka Jagiellońska, rkps, 9070 III, k. 148-149.

Księa zmarlych chrześcijan 1923, t. 1 (Kraków: 1923).

„Liber defunctorum - księga zgonów Parafii Św. Szczepana w Krakowie”, rkps.

List C.K. Galicyjskiej Dyrekcji Skarbu L.17210/15 do Pana Jana Pawła Piekarza lustratora Rady powiatowej, mps, rkps (Biała: 27.04.1915).

List c.k. Wydziału Krajowego we Lwowie do Stanisława Daczyńskiego Lw. 34.082, rkps (Lwów: 27.03.1918).

List do Stanisława Daczyńskiego - odpis listu c.k. Wydziału Krajowego w Białej do c.k. Urzędu podatkowego w Bochni, mps, rkps (28.10.1916).

List Jana Piekarza do Stanisława Daczyńskiego, mps, rkps (Bochnia: 18.04.1915). List Ministerstwa Wyznań Religijnych i Oświecenia Publicznego do Stanisława Daczyńskiego, mps (Warszawa: 01.02.1921).

List Wydziału Krajowego we Lwowie do Stanisława Daczyńskiego, Lw. 48.825, rkps (Lwów: 03.03.1920).

List Wydziału Krajowego we Lwowie do Stanisława Daczyńskiego, Lw. 16.177, rkps (Lwów: 07.05.1920).

List Wydziału Krajowego we Lwowie do Stanisława Daczyńskiego, Lw. 29.836, mps, rkps (Lwów: 04.08.1920).

List Wydziału Krajowego we Lwowie do Stanisława Daczyńskiego, Lw. 29.245, mps, rkps, (Lwów: 27.10.1920).

Mardyrosiewicz Bohdan, „Szkoła Garncarska w Kołomyi”, Świat: dwutygodnik ilustrowany 4 (1891): 225-234.

Skawiński Czesław, „Towarzystwo «Sztuka Podhalańska» w Zakopanem”, Giewont. Ilustrowany kwartalnik zakopiański poświęcony sztuce, literaturze i sprawom rozwoju Zakopanego 1 (1924): 19-20.

Zaremba, „Roczna wystawa w akademii sztuk pięknych”, Gazeta Polska 170 (1.08.1883): 2. 


\section{Książki i monografie}

Buyko Małgorzata, Jarmuł-Niemczyk Katarzyna, Kania Izabela, Artyści ze szkoły Jana Matejki: wystawa jubileuszowa w 80. rocznicę początków i w 20. rocznicę restytucji Muzeum Śląskiego w Katowicach (Katowice: Muzeum Śląskie, 2004).

Borowik Aneta, Dzieje, architektura oraz twórcy Zakładu OO. Jezuitów w Chyrowie Twórczość Antoniego Łuszczkiewicza oraz Edgara Kovátsa na tle epoki (Katowice: Wydawnictwo UŚ, 2012).

Brzezina Maria, Stylizacja huculska (Kraków: Universitas, 1992).

Brykowski Ryszard, Kołomyja: jej dzieje, zabytki (Warszawa: Wydawnictwo Indruk, 1998).

Dobrowolski Tadeusz, Sztuka Młodej Polski (Warszawa: PWN, 1963).

Duda Krzysztof, „Pokuckie i huculskie inspiracje twórczości Stanisława Daczyńskiego w świetle listów do Seweryna Böhma”, w Kołomyja, Pokucie i Huculszczyzna w II Rzeczpospolitej. Wybrane zagadnienia, red. Adam Adrian Ostanek, Aleksander Smoliński (Warszawa: Wydawnictwo Stara Szuflada, 2017).

Gzella Grażyna, „Szynalewski Feliks Jan Nepomucen”, w Polski Słownik Biograficzny, t. 50, red. Andrzej Romanowski (Warszawa-Kraków: Polska Akademia Umiejętności, 2015), 192-195.

Huml Irena, „Kryciński Walerian”, w Polski Słownik Biograficzny, t. 15, red. Emanuel Rostworowski (Wrocław-Warszawa-Kraków: Polska Akademia Umiejętności, 1970), 453-454.

Kryciński Walerian, Rysunki odręczne, zdobnicze i malarstwo dekoracyjne. Nowe metody nauczania $w$ szkołach różnych typów, według planów Ministerstwa W.R I O.P. (Lwów-Warszawa-Kraków: Wydawnictwo Ossolineum, 1926).

Kudelska Dorota, Dukt pisma i pędzla. Biografia intelektualna Jacka Malczewskiego (Lublin: Wydawnictwo KUL, 2008).

Listy Stanisława Wyspiańskiego. Różne - do wielu adresatów, red. Maria Rydlowa (Kraków: Wydawnictwo Literackie, 1998).

Melbechowska-Luty Aleksandra, „Daczyński Stanisław Leopold Maksymilian”, w Słownik artystów polskich i obcych w Polsce działających. Malarze-rzeźbiarze-graficy, t. 2, red. Jolanta Maurin-Białostocka et al. (Wrocław-Warszawa-Kraków-Gdańsk: Wydawnictwo Ossolineum, 1975).

Nicieja Stanisław Sławomir, Kresowa Atlantyda. Historia i mitologia miast kresowych: Kołomyja, Żabie, Dobromil, t. 4 (Opole: Wydawnictwo MS, 2014).

Polanowska Jolanta, „Władysław Łuszczkiewicz”, w Słownik artystów polskich i obcych $w$ Polsce działających. Malarze, rzeźbiarze, graficy, t. 5, red. Jolanta Maurin-Białostocka et al. (Warszawa: Krąg, 1993).

Seweryn Tadeusz, Pokucka majolika ludowa (Kraków: Polska Akademia Umiejętności, 1929).

Siódme sprawozdanie c.k. Państwowej Szkoły Przemysłowej we Lwowie za rok szkolny 1898/99 (Lwów: Państwowa Szkoła Przemysłowa, 1899). 
Sprawozdanie z czynności Komisji krajowej dla spraw przemysłowych za czas od 15 grudnia 1898 do 18 grudnia 1899 (Lwów: Związkowa Drukarnia we Lwowie, 1899).

Sprawozdanie z działalności Ligi Pomocy Przemysłowej za czas od 15. sierpnia 1908, do 31. grudnia 1909, t. j. za szósty rok istnienia (Lwów: Liga Pomocy Przemysłowej, 1910).

Surma Tomasz, Sygnatury polskich twórców ekslibrisów od XIX wieku do wspótczesności. Leksykon (Warszawa: self-publishing, 2013).

Swieykowski Emmanuel, Pamiętnik Towarzystwa Przyjaciół Sztuk Pięknych w Krakowie 1854-1904: pięćdziesiąt lat działalności dla sztuki ojczystej (Kraków: Towarzystwo Sztuk Pięknych w Krakowie, 1906).

Szypowska Maria, Jan Matejko wszystkim znany (Poznań: Zysk i S-ka, 2016).

Woźniakowski Jacek, „O wystawach «Sztuki Podhalańskiej»”, Roczniki Humanistyczne 26/2 (1896): 525-530.

Żuk Igor, Julian Zachariewicz 1837-1898, Alfred Zachariewicz 1871-1937: wystawa twórczości. Katalog (Warszawa: Stowarzyszenie Architektów Polskich Oddział Warszawski, 1996).

\section{Czasopisma}

Kawulok Michał, „Artystyczna droga Jana Wałacha do niepodległej Polski”, Echo Wisty 237 (2018): 9.

Köhler Piotr, „Etnobotanika Podhala na podstawie ankiety Józefa Rostafińskiego (1850-1923) z 1883 r., Etnobiologia Polska 8 (2018): 39-98.

Markowski Dariusz, „Straty wojenne malarstwa w zbiorach Muzeum Okręgowego im. Leona Wyczółkowskiego w Bydgoszczy", Cenne, bezcenne, utracone. Valuable, Priceless, Lost 2/51 (2007): 27-33.

\section{Źródła internetowe}

Rzecz o Morskim Oku, tatrzańskich stawach i górach we mgle w twórczości Stanisława Gałka, https://polskiemuzy.pl/rzecz-o-morskim-oku-tatrzanskich-stawach-i-gorach-we-mgle-w-tworczosci-stanislawa-galka- (dostęp: 16.11.2020). 
